\title{
Concentration-weighted trajectory approach to identifying potential sources of speciated atmospheric mercury at an urban coastal site in Nova Scotia, Canada
}

\author{
I. Cheng ${ }^{1}$, L. Zhang ${ }^{2}$, P. Blanchard ${ }^{2}$, J. Dalziel ${ }^{3}$, and R. Tordon ${ }^{3}$ \\ ${ }^{1}$ Independent researcher, 5785 Yonge Street, Toronto, Ontario M2M 4J2, Canada \\ ${ }^{2}$ Air Quality Research Division, Science and Technology Branch, Environment Canada, 4905 Dufferin Street, \\ Toronto, Ontario M3H 5T4, Canada \\ ${ }^{3}$ Air Quality Sciences Section, Environment Canada, 45 Alderney Drive, Dartmouth, Nova Scotia B2Y 2N6, Canada \\ Correspondence to: L. Zhang (leiming.zhang@ec.gc.ca)
}

Received: 3 January 2013 - Published in Atmos. Chem. Phys. Discuss.: 14 February 2013

Revised: 21 May 2013 - Accepted: 23 May 2013 - Published: 23 June 2013

\begin{abstract}
Regional and local sources contributing to gaseous elemental mercury (GEM), gaseous oxidized mercury (GOM), and particle-bound mercury (PBM) at an urban coastal site in Dartmouth, Nova Scotia, Canada were investigated using the Concentration-Weighted Trajectory model (CWT) and Conditional Probability Function. From 2010-2011, GEM, GOM, and PBM concentrations were $1.67 \pm 1.01 \mathrm{ng} \mathrm{m}^{-3}, 2.07 \pm 3.35 \mathrm{pg} \mathrm{m}^{-3}$, and $2.32 \pm 3.09 \mathrm{pg} \mathrm{m}^{-3}$, respectively. Seasonal variability was observed, with statistically higher GEM and PBM concentrations in winter and spring and higher GOM in spring. In the CWT, concentrations are the weighting factors for the trajectory residence time in modeled grid cells, which results in the identification of source areas based on the CWT values in the grid cells. Potential source areas were identified in regions with known industrial $\mathrm{Hg}$ sources particularly in the fall season, but also in regions without these sources (e.g. Atlantic Ocean, northern Ontario and Quebec). CWTs for GOM and PBM that were associated with $\geq 5 \mathrm{~kg}$ industrial $\mathrm{Hg}$ emissions from 2010-2011 were statistically larger than those with zero $\mathrm{Hg}$ emissions, despite a lack of strong correlations. A large proportion of elevated CWTs (85-97\%) was in regions with zero industrial $\mathrm{Hg}$ sources indicating the potential role of non-point sources, natural emissions, and residential-scale combustion. Analysis of wind data suggests that a commercial harbor and vehicular traffic were potential local sources. Evaluating modeled source areas against $\mathrm{Hg}$ emissions inventories was not an ideal method for assessing
\end{abstract}

the CWT model accuracy because of insufficient data on $\mathrm{Hg}$ emissions at more precise locations.

\section{Introduction}

Speciated atmospheric mercury concentrations have been measured at many urban locations across the United States, including Detroit (Liu et al., 2007, 2010), Houston (Brooks et al., 2010), Tuscaloosa (Gabriel et al., 2005), Reno (Lyman and Gustin, 2009; Peterson et al., 2009), Birmingham (Nair et al., 2012), Milwaukee (Rutter et al., 2007), and Rochester (Huang et al., 2010). In Canada, these measurements have taken place at two urban locations: Toronto (Song et al., 2009) and Windsor (Xu and Akhtar, 2010). A common trend among urban sites is the higher average gaseous elemental mercury (GEM), gaseous oxidized mercury (GOM), and fine particle-bound mercury (PBM) concentrations compared to rural and remote sites (Ebinghaus et al., 2010). Large variability and frequent peaks in speciated atmospheric $\mathrm{Hg}$ concentrations, particularly for GOM, were also characteristics of urban sites. These observations were typically attributed to major sources of $\mathrm{Hg}$ surrounding the urban sites, such as coal-fired power plants and industrial facilities. However, not all urban sites were located near combustion and industrial sources; therefore in these cases, the sources were attributed to regional and long-range transport of $\mathrm{Hg}$ emissions and 
local vehicular emissions and surface emissions (Lynam and Keeler, 2006; Cheng et al., 2009; Xu and Akhtar, 2010).

To determine potential sources contributing to GEM, GOM, and PBM concentrations at a particular site requires data analysis and modeling. When long-term measurements are available, receptor-based methods can be used to carry out such studies (Hopke and Cohen, 2011; Cheng et al., 2012). One of the most common receptor models is back trajectory modeling. It is widely used to study potential sources of atmospheric $\mathrm{Hg}$ because the model simulates airflow patterns from the receptor site which is a major mechanism for pollutant transport. Back trajectory modeling is used in conjunction with atmospheric $\mathrm{Hg}$ concentrations measured at the receptor site and are commonly referred to as Hybrid Receptor Models (Han et al., 2007) or Trajectory Statistical Methods (TSMs) (Kabashnikov et al., 2011). When the results are plotted on a map, these models illustrate potential source areas affecting a receptor site. There are several variations of TSMs that have been applied to speciated atmospheric $\mathrm{Hg}$ studies: Potential Source Contribution Function (PSCF) (Han et al., 2005, 2007; Abbott et al., 2008; Choi et al., 2008; Xu and Akhtar, 2010; Fu et al., 2011), Gridded Frequency Distributions (GFD) (Weiss-Penzias et al., 2011; Gustin et al., 2012), Concentration Fields Analysis (Rutter et al., 2009) or Concentration-Weighted Trajectory (CWT), and Residence Time Weighted Concentration (RTWC) (Han et al., 2007). They all involve counting the frequency of back trajectory segment endpoints in grid cells that make up the geographical domain of interest for the receptor site. The main difference has to do with how the $\mathrm{Hg}$ concentrations are incorporated with the trajectory endpoint frequencies in each grid cell.

PSCF shows the percent frequency of trajectory segment endpoints above a concentration threshold relative to the total trajectory segment endpoints in each grid cell. GFD provides an average frequency of the trajectory endpoints for an ensemble of trajectories (i.e. multiple starting heights and starting locations) for events associated with high pollutant concentrations. In CWT, every concentration is used as a weighting factor for the residence times of all trajectories in each grid cell and then divided by the cumulative residence time from all trajectories. RTWC applies a similar concept; however, concentrations are equally divided along each trajectory initially and then the logarithm of the redistributed concentrations is used as a weighting factor. Some of these models have been reviewed by Watson et al. (2008), which include a summary of the models' strengths and weaknesses. Model comparisons found comparable results when Concentration Fields (using logarithmic concentrations), CWT, and PSCF were applied to virtual sources and modeled concentrations (Kabashnikov et al., 2011). When applied to field carbonaceous aerosols and PM measurements, good agreement was attained between PSCF and CWT models (Jeong et al., 2011). Han et al. (2007) conducted comparisons between PSCF and RTWC and found there were some differences in the source areas identified for total gaseous mercury concentrations. Based on the literature review, TSMs have not been extensively applied to field measurements of speciated atmospheric $\mathrm{Hg}$. Aside from identifying the location of potential source areas, there seems to be a lack of detailed comparison between the modeled source areas and sources of $\mathrm{Hg}$ from national emissions inventories and research-derived emissions inventories to properly assess the accuracy, uncertainties, and limitations of TSMs.

The objective of this study was to identify regional source areas contributing to speciated atmospheric $\mathrm{Hg}$ measurements at an urban site in Dartmouth, Nova Scotia, Canada by applying the Concentration-Weighted Trajectory (CWT) model. The analysis included a discussion of the location of the potential source areas identified by CWT and the types of known industrial $\mathrm{Hg}$ sources within the source areas. The study conducted statistical analysis to compare CWTs with industrial $\mathrm{Hg}$ emissions reported in Canadian and US emissions inventories and examined the role of non-point sources, natural emission, and other sources. To address potential local sources of $\mathrm{Hg}$, an analysis of wind speeds and wind direction was also conducted using Conditional Probability Function.

\section{Methods}

\subsection{Site description}

The speciated atmospheric mercury sampling site is located on a 3rd floor roof platform of a building in downtown Dartmouth, Nova Scotia, Canada $\left(44^{\circ} 39^{\prime} 54.71^{\prime \prime} \mathrm{N}\right.$, $\left.63^{\circ} 34^{\prime} 9.69^{\prime \prime} \mathrm{W}\right)$. Dartmouth is part of the Halifax Regional Municipality, which is on the south-central shore of Nova Scotia and comprised of four other municipalities including the former City of Halifax. Together, the population in 2011 was $\sim 390000$ (Statistics Canada, 2012). The area surrounding the sampling site consists of commercial areas and an active commercial harbor (Halifax Harbor) that leads to the Atlantic Ocean. There are two known Hg sources near Dartmouth with relatively small $\mathrm{Hg}$ emissions $\left(<3 \mathrm{~kg} \mathrm{yr}^{-1}\right)(\mathrm{En}$ vironment Canada, 2012): one of the sources is from a university in downtown Halifax and the other source is an oil refinery in Dartmouth (Fig. 1, top right). A slightly larger $\mathrm{Hg}$ source is a cement plant located $\sim 66 \mathrm{~km}$ from Dartmouth. On a regional scale (Fig. 1), the largest concentration of industrial $\mathrm{Hg}$ sources is found in southern Ontario and Quebec, and in Pennsylvania, Ohio, West Virginia, and Maryland (Environment Canada, 2012; USEPA, 2012a).

\subsection{Speciated atmospheric Hg measurements}

The study analyzed gaseous elemental mercury (GEM), gaseous oxidized mercury (GOM), and fine particle-bound mercury $<2.5 \mu \mathrm{m}(\mathrm{PBM})$ that were measured from January 2010 to December 2011. Mercury sampling and analysis was carried out using a Tekran system incorporating both the 

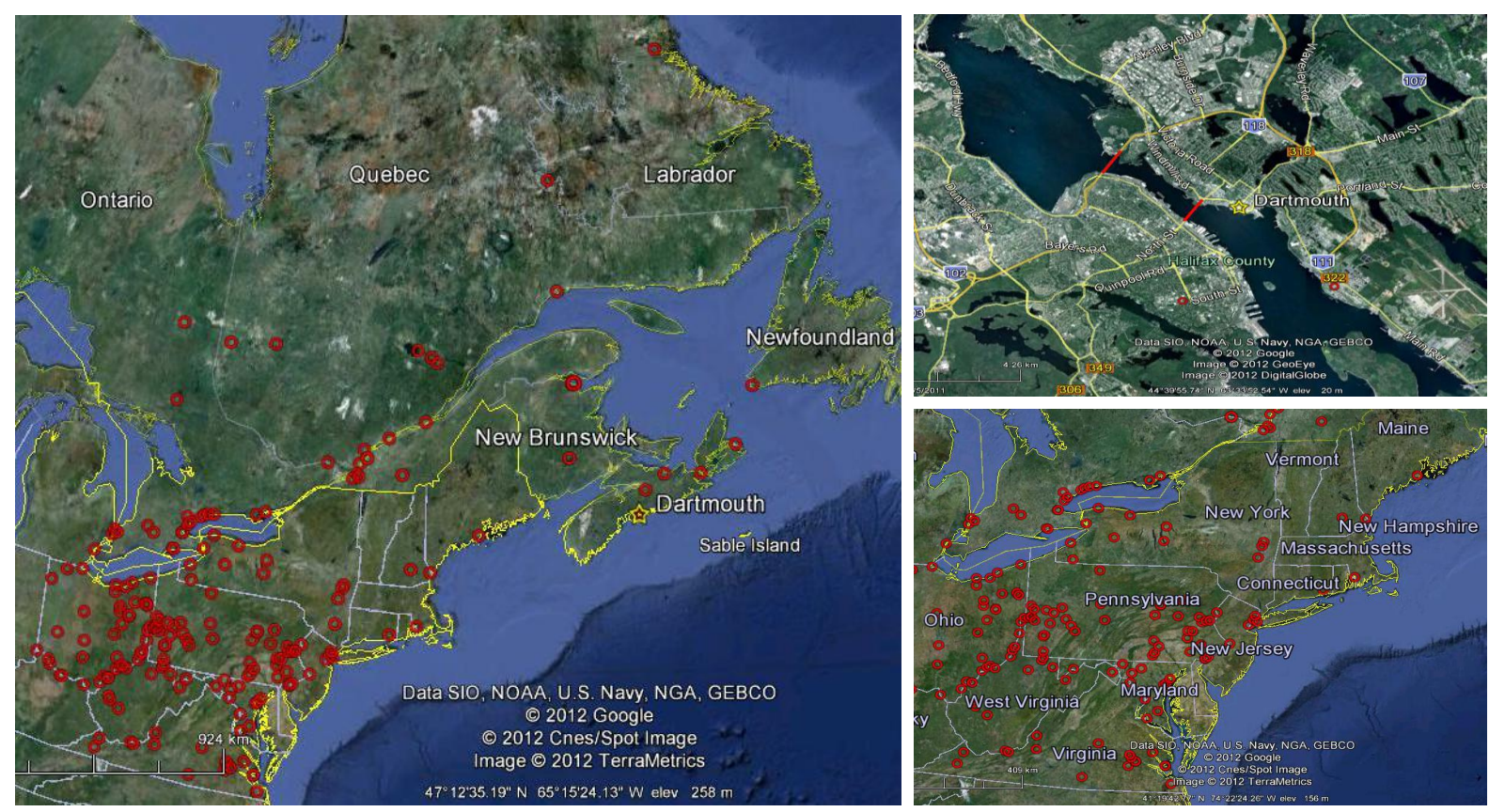

Fig. 1. Map showing the Dartmouth site and the locations of known industrial $\mathrm{Hg}$ sources (labeled with red circles) within a geographical domain. Top right and bottom right images are enlarged to show Dartmouth and the US northeast, respectively. Locations of known industrial $\mathrm{Hg}$ sources emitting $>5 \mathrm{~kg} \mathrm{Hg} \mathrm{yr}^{-1}$ in 2010 and 2011 were retrieved from National Pollutant Release Inventory (Environment Canada, 2012) and Toxics Release Inventory (USEPA, 2012a).

2537A $\mathrm{Hg}$ analyzer and the 1130/1135 speciation sampling units. A Tekran air dryer unit (Model 1102A) was used with the $1130 \mathrm{pump} /$ controller to supply zero air free of $\mathrm{Hg}$ and analytical artifacts. Ambient air was sampled for a $2 \mathrm{~h}$ cycle for GOM and PBM at a flow of $10 \mathrm{~L} \mathrm{~min}^{-1}$. The GOM fraction was collected on a $\mathrm{KCl}$-coated quartz denuder and the PBM was collected on a quartz filter. During the $2 \mathrm{~h}$ sampling period, $5 \mathrm{~min}$ integrated samples of GEM were continuously quantified with the 2537A analysis unit. This $2 \mathrm{~h}$ sampling cycle was followed by a $1 \mathrm{~h}$ desorption and analysis cycle for PBM and GOM. Each sampling and desorption cycle lasted three hours for a total of eight sets of GOM and PBM data per day. GEM data were averaged to match the GOM and PBM data resolution. Operation, calibration, and maintenance of the $\mathrm{Hg}$ speciation system followed Atmospheric Mercury Network (AMNet) procedures (NADP, 2012). The speciated atmospheric Hg data were verified using Environment Canada's Research Data Management Quality (RDMQ) software and stored in the Canadian National Atmospheric Chemistry (NAtChem) Database. The software flags data using multiple performance checks including baseline stability, calibration response, contamination, sample volume, and variability between dual sampling cartridges. These data QA-QC checks along with rigorous sampling and maintenance protocols have contributed to a quality control standard for atmospheric mercury species measurements (Steffen et al., 2012).

\subsection{Additional data}

To explain the source areas identified from the study, mercury emissions data from industrial sources located in Canada and the US were obtained from the National Pollutant Release Inventory (Environment Canada, 2012) and Toxics Release Inventory (USEPA, 2012a), respectively. This includes annual $\mathrm{Hg}$ emissions from the stack in 2010 and 2011 and the geographical coordinates of the facilities. When applicable, non-industrial $\mathrm{Hg}$ emissions data related to transportation, residential combustion, and marine commercial vessels and shipping ports were obtained from the 2008 National Emissions Inventory (NEI) (USEPA, 2012b). For the analysis of local $\mathrm{Hg}$ sources, wind speed and wind direction data measured at the sampling site were also utilized. No other pollutant concentrations were measured at the site.

\subsection{Conditional Probability Function (CPF)}

For the analysis of local sources of $\mathrm{Hg}$ affecting GEM, GOM, PBM concentrations at Dartmouth, the probability of winds associated with elevated speciated atmospheric Hg concentrations (defined as $\geq 75$ th percentile for each $\mathrm{Hg}$ species and each season) from each of the eight wind direction sectors were determined. This is also known as the conditional probability function as previously described in Liu et al. (2007), Watson et al. (2008), and Huang et al. (2010). The analysis used wind direction data measured at the Dartmouth site. 
Only wind speeds $>1 \mathrm{~m} \mathrm{~s}^{-1}$ were included in the CPF analysis. CPFs range from 0 (low probability of winds coinciding with elevated concentrations) to 1 (high probability of winds coinciding with elevated concentrations). Once the wind directions associated with high CPFs are identified, potential local sources of $\mathrm{Hg}$ can be found by referring to National Pollutant Release Inventory (Environment Canada, 2012) for known industrial $\mathrm{Hg}$ sources.

\subsection{Determination of Concentration-Weighted Trajectory (CWT)}

CWTs were used to locate regional source areas potentially affecting GEM, GOM, and PBM concentrations at Dartmouth. CWT is a function of GEM, GOM, or PBM concentrations that were reported every $3 \mathrm{~h}$ and the residence time of a trajectory arriving at Dartmouth in each grid cell. For every concentration one back trajectory was generated, for a total of 5178 back trajectories from 2010-2011. From this perspective, it is different from Potential Source Contribution Function (PSCF), which focuses on the residence time of a trajectory in each grid cell only above an arbitrary concentration threshold. The concentrations are not explicitly included in the PSCF calculation and there is no requirement on how many back trajectories need to be generated. Other studies suggested that PSCF may be omitting source areas that fall slightly below the concentration threshold (Wang et al., 2009; Jeong et al., 2011).

Prior to determining the CWTs, back trajectories corresponding to the sampling cycle of each $3 \mathrm{~h}$ GEM, GOM, and PBM measurement were generated using the HYSPLIT4 model (Draxler and Rolph, 2012; Rolph, 2012). Since there were eight sets of GEM, GOM, and PBM measurements per day as previously mentioned, eight back trajectories were generated for each sampling day at 00:00, 03:00, 06:00, ..., 21:00 local AST (Atlantic Standard Time). The model parameters selected were the EDAS $40 \mathrm{~km}$ archive meteorological data from the NWS NCEP, trajectory duration of $48 \mathrm{~h}$, and starting height of $100 \mathrm{~m}$ a.s.l. (above sea level). The hourly trajectory segment endpoints for each back trajectory that corresponds to each $3 \mathrm{~h} \mathrm{Hg}$ concentration were retained. For a $48 \mathrm{~h}$ trajectory duration, there were normally 48 trajectory segment endpoints.

Based on the maximum distance traveled by the back trajectories over the 2010-2011 period, a geographical domain from 35 to $55^{\circ} \mathrm{N}$ and from 85 to $55^{\circ} \mathrm{W}$ was found to be suitable. This domain encompasses the locations of nearly all the trajectory segment endpoints from all the back trajectories and known regional industrial $\mathrm{Hg}$ sources. The geographical domain was divided into 2400 grid cells ( 40 grid cells across the latitude by 60 grid cells across the longitude), each covering an area of $0.5^{\circ}$ by $0.5^{\circ}$.

The CWT for GEM, GOM, and PBM for a particular grid cell $(i, j)$ is a measure of the source strength of a grid cell to the Dartmouth site and is determined as follows (Jeong et al.,
2011; Kabashnikov et al., 2011):

$\mathrm{CWT}_{i j}=\frac{\sum_{l=1}^{L} C_{l} \tau_{i j l}}{\sum_{l=1}^{L} \tau_{i j l}}$

$C_{l}$ is the $3 \mathrm{~h}$ GEM, GOM, or PBM concentration corresponding to the arrival of back trajectory $l$; $\tau_{i j l}$ is the number of trajectory segment endpoints in grid cell $(i, j)$ for back trajectory $l$ divided by the total number of trajectory segment endpoints for back trajectory $l$ (i.e. residence time of a trajectory in each grid cell); $L$ is the total number of back trajectories over a time period (e.g. each season). Given $C_{l}$ for GEM, GOM, and PBM, $\tau_{i j l}$ can be determined by counting the number of hourly trajectory segment endpoints from the HYSPLIT model in each grid cell for each trajectory. This was repeated for all the back trajectories, $L$.

CWTs for GEM, GOM, and PBM were determined for each season (Winter: December, January, February; Spring: March, April, May; Summer: June, July, August; Fall: September, October, November), which consisted of both the 2010 and 2011 data. Seasonal CWTs were calculated because a seasonal cycle in speciated atmospheric Hg concentrations has been observed at other locations. This could be the result of changes in sources and meteorology, such as airflow patterns, which affect the trajectory residence times in the determination of CWTs. The CWTs were color-coded based on the seasonal percentile of the CWTs and plotted over a Google Earth map to highlight potential major source areas for GEM, GOM, and PBM affecting Dartmouth (defined by $\geq 90$ th percentile CWTs in each season). Grid cells with $<2$ trajectory segment endpoints were shaded in grey, indicating that there are uncertainties in the seasonal CWTs due to the small number of endpoints (i.e. unlikely for airflow to pass over a particular area). Known as the tailing effect, the few number of trajectory segment endpoints can lead to the false identification of source areas because the concentrations are uniformly weighted along a trajectory (Watson et al., 2008; Jeong et al., 2011). Although a minimum of 2 trajectory segment endpoints per grid cell seems like a small number, it is equivalent to two sets of $3 \mathrm{~h} \mathrm{Hg}$ concentrations and trajectory residence times in the seasonal CWT calculation. After including the known industrial $\mathrm{Hg}$ (point) sources on the CWT plots, the types of industrial $\mathrm{Hg}$ sources within the major source areas can be identified. Hg emissions intensity for each grid cell was also computed by summing the $\mathrm{Hg}$ emissions from known industrial sources in each of the grid cells. Afterwards, statistical comparisons were made between total $\mathrm{Hg}$ emissions for each grid cell and the corresponding CWT. 
Table 1. Speciated atmospheric Hg concentrations (mean \pm standard deviation) at Dartmouth and urban locations in Canada and United States.

\begin{tabular}{|c|c|c|c|c|c|}
\hline Location & Sampling period & $\begin{array}{l}\text { GEM } \\
\mathrm{ng} \mathrm{m}^{-3}\end{array}$ & $\begin{array}{l}\mathrm{GOM} \\
\mathrm{pg} \mathrm{m}^{-3}\end{array}$ & $\begin{array}{l}\mathrm{PBM} \\
\mathrm{pg} \mathrm{m}^{-3}\end{array}$ & Reference \\
\hline $\begin{array}{l}\text { Dartmouth, Nova } \\
\text { Scotia, Canada }\end{array}$ & 2010-2011 & $1.67 \pm 1.01$ & $2.07 \pm 3.35$ & $2.32 \pm 3.09$ & This study \\
\hline $\begin{array}{l}\text { Toronto, Ontario, } \\
\text { Canada }\end{array}$ & $\begin{array}{l}\text { Dec 2003- } \\
\text { Nov } 2004\end{array}$ & $4.5 \pm 3.1$ & $14.2 \pm 13.2$ & $21.5 \pm 16.4$ & Song et al. (2009) \\
\hline $\begin{array}{l}\text { Windsor, } \\
\text { Ontario, Canada }\end{array}$ & 2007 & $2.02 \pm 1.63$ & - & - & $\mathrm{Xu}$ and Akhtar (2010) \\
\hline $\begin{array}{l}\text { Detroit, } \\
\text { Michigan }\end{array}$ & $\begin{array}{l}2003 \\
2004\end{array}$ & $\begin{array}{l}2.2 \pm 1.3 \\
2.5 \pm 1.4\end{array}$ & $\begin{array}{l}17.7 \pm 28.9 \\
15.5 \pm 54.9\end{array}$ & $\begin{array}{l}20.8 \pm 30.0 \\
18.1 \pm 61.0\end{array}$ & Liu et al. $(2007,2010)$ \\
\hline $\begin{array}{l}\text { Rochester, } \\
\text { New York }\end{array}$ & $\begin{array}{l}\text { Summer 2008- } \\
\text { Spring } 2009\end{array}$ & $1.49 \pm 0.27$ & $4.08 \pm 7.83$ & $6.57 \pm 6.11$ & Huang et al. (2010) \\
\hline $\begin{array}{l}\text { Bronx, } \\
\text { New York* }\end{array}$ & 2008-2009 & 1.51 & 7.05 & 7.58 & Zhang et al. (2012) \\
\hline $\begin{array}{l}\text { New Brunswick, } \\
\text { New Jersey* }\end{array}$ & 2008-2009 & 2.07 & 2.30 & 5.80 & Zhang et al. (2012) \\
\hline $\begin{array}{l}\text { Beltsville, } \\
\text { Maryland* }\end{array}$ & 2008-2009 & 1.30 & 3.01 & 4.99 & Zhang et al. (2012) \\
\hline $\begin{array}{l}\text { Birmingham, } \\
\text { Alabama }\end{array}$ & $2005-2008$ & $2.12 \pm 1.57$ & $78.2 \pm 441.9$ & $39.5 \pm 147.9$ & Nair et al. (2012) \\
\hline $\begin{array}{l}\text { Milwaukee, } \\
\text { Wisconsin }\end{array}$ & $\begin{array}{l}\text { Jun 2004- } \\
\text { May } 2005\end{array}$ & $2.48 \pm 0.02$ & $10.3 \pm 0.2$ & $11.8 \pm 0.3$ & Rutter et al. (2007) \\
\hline Houston, Texas & Aug-Oct 2006 & $1.66 \pm 0.36$ & $6.9 \pm 7.9$ & $2.5 \pm 5.2$ & Brooks et al. (2010) \\
\hline $\begin{array}{l}\text { Salt Lake City, } \\
\text { Utah* }^{*}\end{array}$ & 2008-2009 & 2.12 & 22.61 & 16.03 & Zhang et al. (2012) \\
\hline Reno, Nevada & $\begin{array}{l}\text { Feb 2007- } \\
\text { Jan } 2009\end{array}$ & $2.0 \pm 0.7$ & $18 \pm 22$ & $7 \pm 7$ & Lyman and Gustin (2009) \\
\hline
\end{tabular}

* Average of seasonal means.

\section{Results and discussion}

\subsection{Overall concentrations}

The average and standard deviation of GEM, GOM, and PBM concentrations from 2010-2011 were $1.67 \pm 1.01 \mathrm{ng} \mathrm{m}^{-3}, \quad 2.07 \pm 3.35 \mathrm{pg} \mathrm{m}^{-3}, \quad$ and $2.32 \pm$ $3.09 \mathrm{pg} \mathrm{m}^{-3}$, respectively. The median concentrations of GEM, GOM, and PBM were $1.62 \mathrm{ng} \mathrm{m}^{-3}, 1.1 \mathrm{pg} \mathrm{m}^{-3}$, and $1.6 \mathrm{pg} \mathrm{m}^{-3}$, respectively. A comparison with measurements from other urban locations in Canada illustrated that the mean concentrations at Dartmouth were lower than other major Canadian cities in Table 1. Average GEM concentrations at Dartmouth were within the range of the mean GEM concentrations measured at US urban locations. Average GOM and PBM concentrations at Dartmouth were lower than many of the urban sites listed in Table 1 even after consideration of the 30-40\% uncertainties for GOM concentrations (Gustin and Jaffe, 2010). Previous studies conducted at urban sites have not only observed higher atmospheric $\mathrm{Hg}$ concentrations than those at rural sites, but also larger variability in the concentrations (Gabriel et al., 2005; Song et al., 2009; Liu et al., 2010). The overall variability in GEM concentrations based on relative standard deviation at Dartmouth was comparable to some of the major cities, such as Toronto, Windsor, Detroit, and Birmingham. Based on the time-series plots of GEM, GOM, and PBM (Fig. 2), there were several events with elevated $\mathrm{Hg}$ concentrations, which will be analyzed further using Conditional Probability Function. But the overall variability in GOM and PBM concentrations at Dartmouth was smaller than other urban locations. 

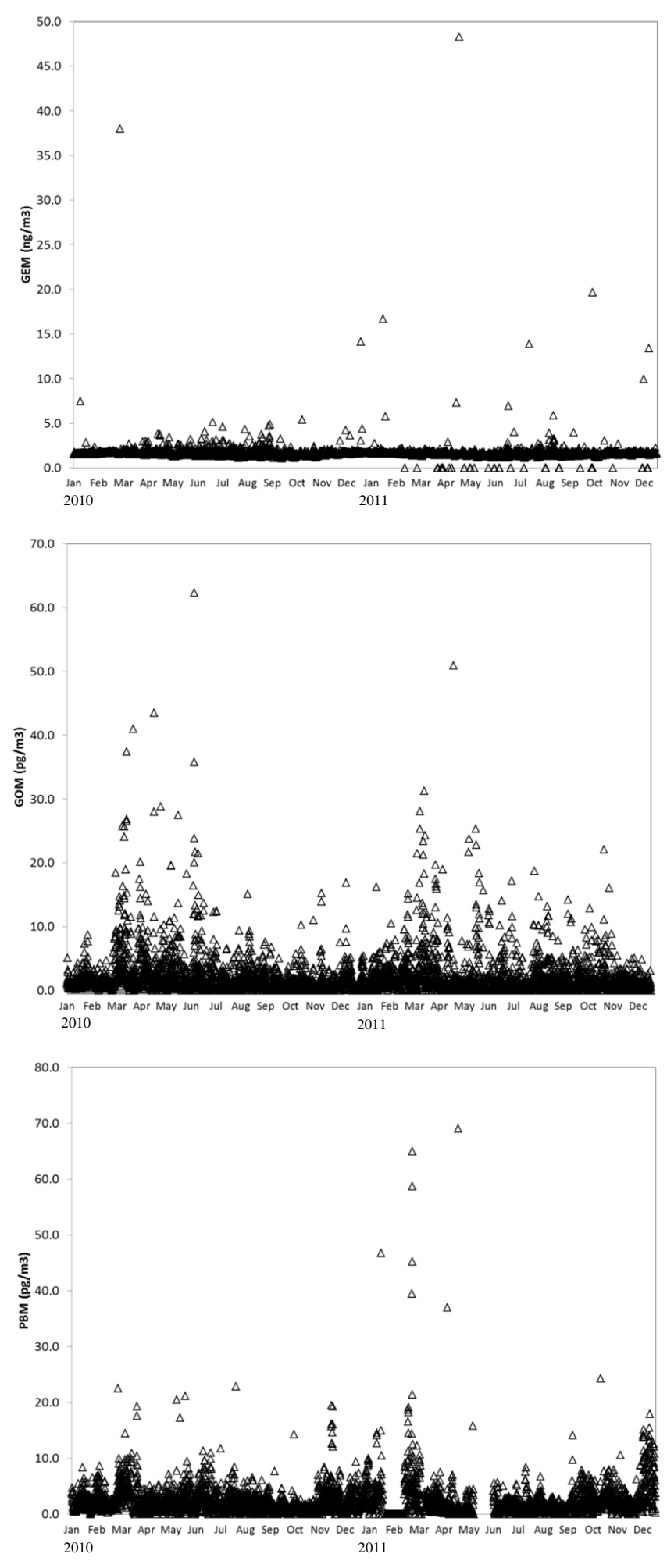

Fig. 2. Time series concentrations of GEM, GOM, and PBM between January 2010 and December 2011.
Table 2. Seasonal GEM $\left(\mathrm{ng} \mathrm{m}^{-3}\right)$, GOM $\left(\mathrm{pg} \mathrm{m}^{-3}\right)$, and PBM $\left(\mathrm{pg} \mathrm{m}^{-3}\right)$ concentrations at Dartmouth (mean \pm standard deviation). Winter: December, January, February; Spring: March, April, May; Summer: June, July, August; Fall: September, October, November. Seasonal concentrations were based on combined data from 2010-2011.

\begin{tabular}{lccc}
\hline & GEM & GOM & PBM \\
\hline Overall & $1.67 \pm 1.01$ & $2.07 \pm 3.35$ & $2.32 \pm 3.09$ \\
\hline Winter & $1.74 \pm 0.75$ & $1.46 \pm 1.51$ & $2.66 \pm 3.16$ \\
Spring & $1.74 \pm 1.72$ & $3.39 \pm 4.89$ & $2.85 \pm 4.49$ \\
Summer & $1.63 \pm 0.57$ & $2.03 \pm 3.55$ & $1.81 \pm 1.80$ \\
Fall & $1.58 \pm 0.57$ & $1.43 \pm 1.96$ & $2.00 \pm 2.15$ \\
\hline
\end{tabular}

\subsection{Seasonal concentrations}

Average GEM and PBM concentrations at Dartmouth were statistically higher in the winter and spring compared to summer and fall $(p<0.05)$ (Table 2$)$. Average GOM concentrations in the spring were statistically higher than those in other seasons. The GEM trend at Dartmouth was partly consistent with other urban sites, where higher average GEM concentrations were typically observed in spring or summer (Liu et al., 2010; Xu and Akhtar, 2010; Nair et al., 2012). This was attributed to enhanced GEM emissions from surfaces during warmer months and regional source emissions (e.g. increased electricity generation) (Liu et al., 2010; Xu and Akhtar, 2010). Seasonal patterns for PBM at Dartmouth were consistent with most of the urban locations in Table 1. The higher PBM concentrations can be explained by increased absorption of gaseous mercury on particles at lower temperatures in winter and regional source emissions (e.g. increased fossil fuel combustion for heating) (Rutter et al., 2007; Lyman and Gustin, 2009; Huang et al., 2010; Liu et al., 2010). However, some sites saw higher average PBM concentrations in spring (Toronto, ON; Beltsville, MD; Birmingham, AL) or fall (Birmingham, AL; Salt Lake City, UT). The higher GOM concentrations in spring at Dartmouth were consistent with some urban sites, including Rochester, New York; Beltsville, Maryland; New Brunswick, New Jersey; The Bronx, New York; and Birmingham, Alabama. However, many of the urban sites also experienced higher GOM concentrations in summer or fall (Rutter et al., 2007; Lyman and Gustin, 2009; Song et al., 2009; Liu et al., 2010). Potential explanations for the seasonal GOM trend include, the influence of point sources (Rutter et al., 2007), increase oxidation of GEM due to the seasonal variation of atmospheric oxidants (Selin and Jacob, 2008; Liu et al., 2010), and free troposphere transport (Lyman and Gustin, 2009). 

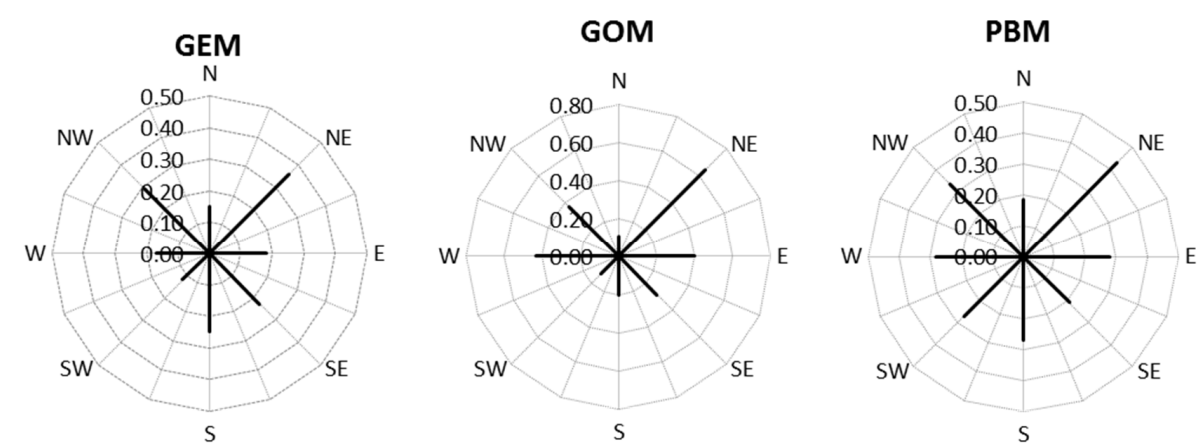

Fig. 3. Probability of winds coinciding with elevated GEM, GOM, and PBM concentrations ( $\geq 75$ th percentile) from each wind direction sector (also known as Conditional Probability Function).

\subsection{Local sources of $\mathrm{Hg}$ from Conditional Probability Function (CPF)}

Wind direction and wind speed data collected at Dartmouth were analyzed with GEM, GOM, and PBM concentrations to determine potential local sources of $\mathrm{Hg}$. The prevailing wind directions over the entire study (excluding calm wind speeds $<1 \mathrm{~m} \mathrm{~s}^{-1}$ ) and in each season were from the southwest, southeast, and east. Southwest winds were dominant in the winter and fall, while southeast winds were dominant in the spring and summer. Average GEM concentrations were not statistically different between the wind direction sectors for all seasons. Differences in GOM concentrations were statistically lower in the winter, summer and fall when winds were southwest $\left(0.8-1.1 \mathrm{pg} \mathrm{m}^{-3}\right)$ compared to those from northeast $\left(2.9 \mathrm{pg} \mathrm{m}^{-3}\right)$, east $\left(2.1-2.8 \mathrm{pg} \mathrm{m}^{-3}\right)$, and southeast (1.5$\left.3.1 \mathrm{pg} \mathrm{m}^{-3}\right)$. For PBM, larger differences were observed in the summer concentrations when winds were from northeast $\left(7.5 \mathrm{pg} \mathrm{m}^{-3}\right)$ and northwest $\left(3.3 \mathrm{pg} \mathrm{m}^{-3}\right)$ compared to those from east, southeast, south, and southwest (1.4-1.9 $\mathrm{pg} \mathrm{m}^{-3}$ ).

Conditional probability function (CPF) was also used to determine the wind direction frequencies associated with elevated GEM, GOM, and PBM concentrations (seasonal $\geq 75$ th percentile). CPFs for elevated GEM (1.67$\left.1.75 \mathrm{ng} \mathrm{m}^{-3}\right)$, GOM $\left(1.8-4.0 \mathrm{pg} \mathrm{m}^{-3}\right)$, and PBM $(2.5-$ $3.6 \mathrm{pg} \mathrm{m}^{-3}$ ) concentrations are shown in Fig. 3. Generally, the probability of observing elevated atmospheric $\mathrm{Hg}$ concentrations was highest when winds were from westnorthwest, east-northeast, and south. The only known local industrial $\mathrm{Hg}$ source is a cement plant located $66 \mathrm{~km}$ (northnortheast) of Dartmouth. There are shipping ports throughout the Halifax harbor and in the Bedford Basin, which is the north part of the harbor (Fig. 1, top right). These shipping ports are situated $\sim 5 \mathrm{~km}$ west-northwest and south of Dartmouth, which is in the direction of elevated $\mathrm{Hg}$ concentrations. About 1500 cargo vessels and cruises enter the Halifax harbor annually (Port of Halifax, 2012). Although Hg emissions data from Halifax ports were not available, 2008 NEI (USEPA, 2012b) estimated that $\mathrm{Hg}$ emissions from commer- cial marine vessels and ports in US northeast can range from $0.02 \mathrm{~kg}$ in West Virginia to $2.5 \mathrm{~kg}$ in Delaware. These emissions are relatively small compared to some larger industrial point sources, but near Dartmouth, there are no other major industrial sources of $\mathrm{Hg}$.

Another potential $\mathrm{Hg}$ source from the west-northwest direction of Dartmouth is vehicular traffic on the Halifax harbor bridges (Fig. 1, red lines in top right image). The two bridges connecting Dartmouth and Halifax are the A. Murray Mackay bridge (3.5 km northwest) and Angus L. Macdonald bridge ( $1 \mathrm{~km}$ west). On weekdays, there are $\sim 52000$ and $\sim 48000$ vehicles crossing each bridge respectively for a combined total of 34 million vehicle crossings annually (HHB, 2012). Previous studies reported that GEM, GOM, and PBM are emitted from gasoline-powered vehicles (Landis et al., 2007). $\mathrm{Hg}$ emissions from light duty gasolinepowered vehicles in the US northeast can range from $0.8 \mathrm{~kg}$ in Vermont to $14.4 \mathrm{~kg}$ in New York (USEPA, 2012b). This only provides insight into the variability in $\mathrm{Hg}$ emissions from vehicles and not ideal for determining vehicular $\mathrm{Hg}$ emissions for Dartmouth without accounting for population, number of vehicles on the road, road capacity, public transit infrastructure, etc.

Higher CPFs were also observed in the east-northeast direction of Dartmouth, which mainly consists of commercial areas, roads, and a highway that extends from one of the Halifax harbor bridges. Hg emissions from vehicles could impact the site due to the proximity of the site to roads and highways. Aside from a cement plant emitting atmospheric $\mathrm{Hg}$, there is also an open-pit gypsum mine $\sim 40 \mathrm{~km}$ northeast of Dartmouth. Previous studies suggest GEM can be emitted from gypsum products (e.g. wallboards and drywall), in which the gypsum was either mined or synthetically produced by the flue-gas desulfurization process in coal combustion (Shock et al., 2009). Exposure of synthetic gypsum to water also led to increase Hg emissions (Gustin and Ladwig, 2010), which suggests that $\mathrm{Hg}$ may be released from an open-pit gypsum mine during rainfall. However, further measurements need to be taken to verify that naturally-mined gypsum is a source of 


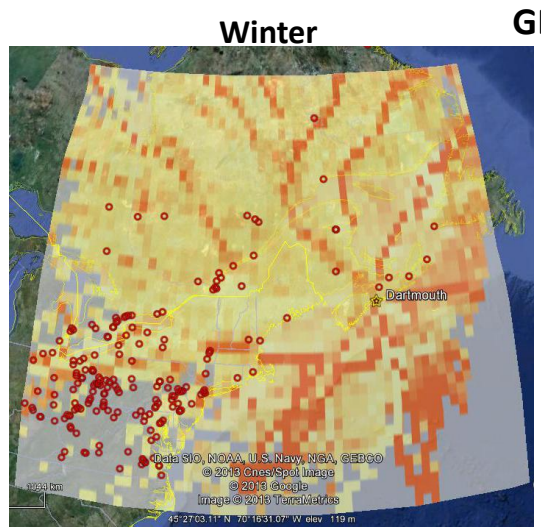

Summer

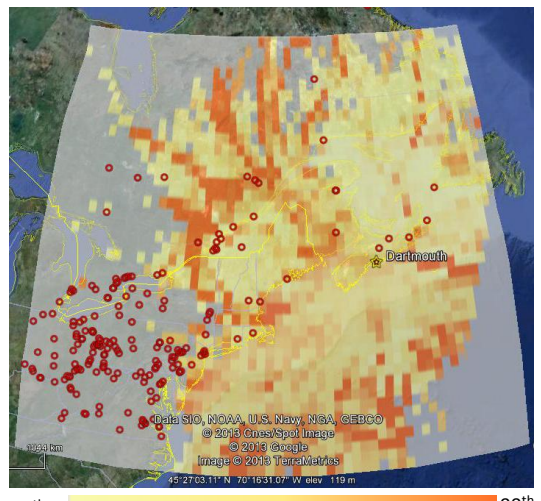

$10^{\text {th }}$

percentile CWT

(non-source areas)
GEM Spring

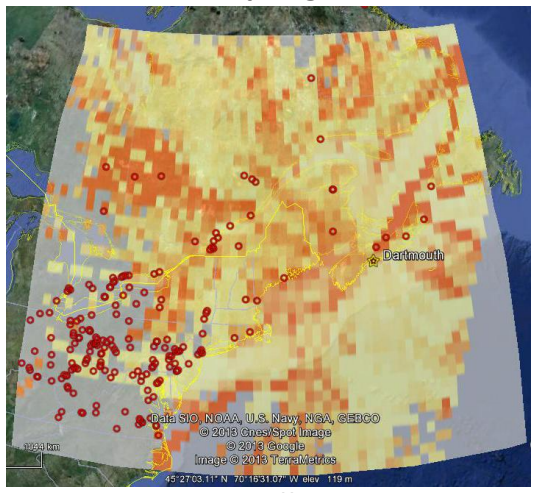

Fall

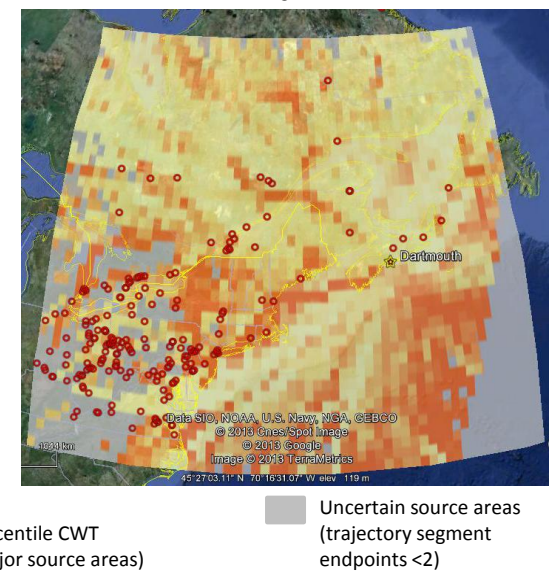

Fig. 4. CWT plots for GEM for each season. Major source areas are dark orange-shaded ( $\geq 90$ th percentile of seasonal CWTs); non-sources areas are light yellow-shaded ( $\leq 10$ th percentile of seasonal CWTs); uncertain source areas are grey-shaded. Red circles are the locations of known industrial $\mathrm{Hg}$ sources emitting $>5 \mathrm{~kg}$ of $\mathrm{Hg} \mathrm{yr}^{-1}$ in 2010 and 2011.

GEM. There is also the possibility that the gypsum mine is a source of PBM, since $\mathrm{Hg}$ is found in trace amounts in geological material and there are large particulate matter emissions from the mine.

Artisanal gold mining is a significant source of $\mathrm{Hg}$ globally (Telmer and Veiga, 2009; Pirrone et al., 2010). Nova Scotia was known for its gold mining industry, which had used mercury amalgamation methods to extract gold (Beauchamp et al., 2002). Historical gold mining districts are scattered throughout the province and several of them are 7.5-30 km east-northeast of Dartmouth (Province of Nova Scotia, 2012), which is associated with elevated atmospheric $\mathrm{Hg}$ concentrations. Today, the gold mines are abandoned; however, the mine tailings still exist and may have contaminated soils, rivers, and lakes nearby (Wong et al., 2002; Parsons et al., 2012). Evasion of GEM from contaminated soils (Beauchamp et al., 2002) and rivers (Maprani et al., 2005) were found to be significant, but further research is needed to track the transport of the gold mine tailings. The resuspension of contaminated soils due to recreational activities is also a potential source of PBM and is currently subject to further research into human health impacts (Parsons et al., 2010).

\subsection{Seasonal Concentration-Weighted Trajectory (CWT) for GEM, GOM, and PBM}

The CWT plots for GEM, GOM, and PBM in Figs. 4 to 6 highlight major source areas affecting speciated atmospheric $\mathrm{Hg}$ concentrations at Dartmouth. Separate plots were created for each season and $\mathrm{Hg}$ species. Dark orange areas have CWTs $\geq 90$ th percentile in each season and represent potential major source areas, whereas the light yellow areas have CWTs $\leq 10$ th percentile in each season and represent weak source areas. The moderate source areas are highlighted orange and have CWTs at the seasonal median. Grey-shaded areas are considered highly uncertain because these grid cells had $<2$ trajectory segment endpoints as previously mentioned. The locations of states and provinces in the description of source areas below can be found in Fig. 1.

The winter CWTs for GEM indicate that the major source areas are potentially in northern Ontario, western and northeastern Quebec, and in some areas of Labrador. Known 


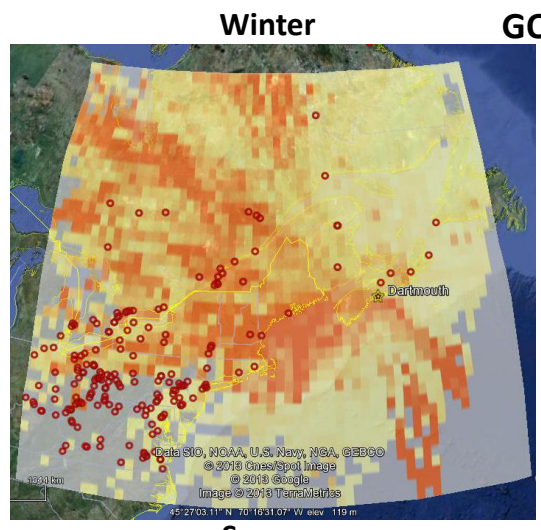

Summer
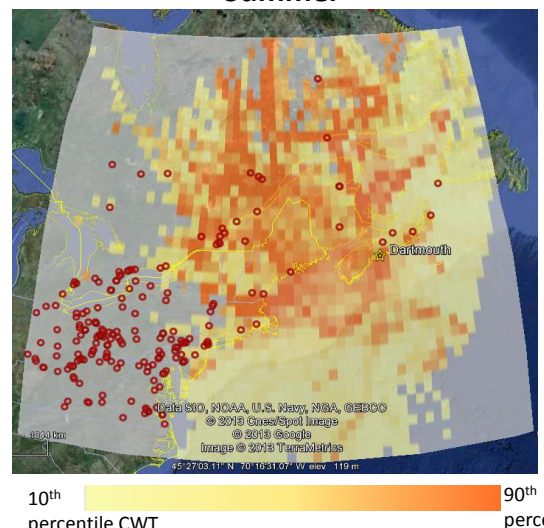

(non-source areas)

percentile CWT (major source areas)
Spring

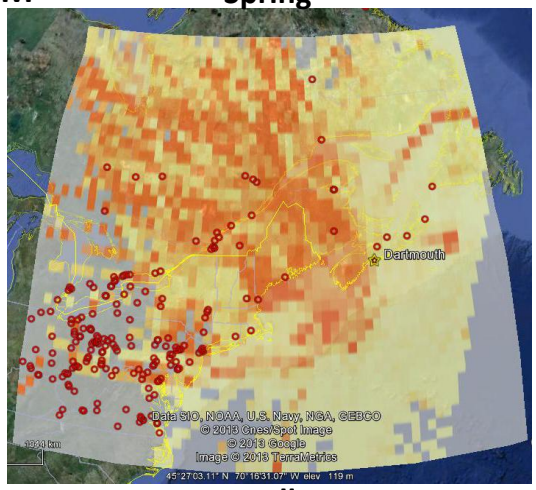

Fall

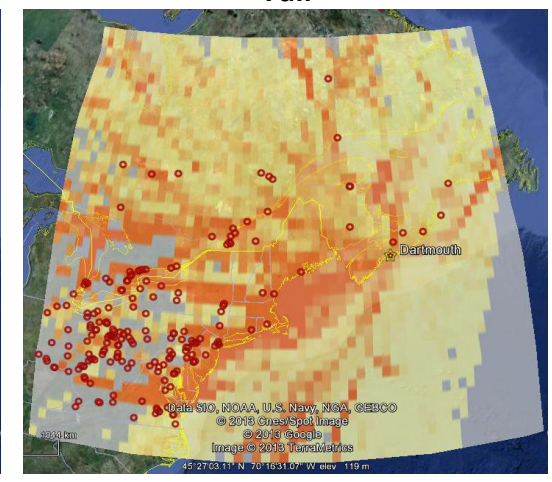

Uncertain source areas (trajectory segment endpoints $<2$ )

Fig. 5. Same as Fig. 4 except for GOM.

industrial $\mathrm{Hg}$ sources in these areas include, metal ore mining in Labrador. The Atlantic Ocean (southwest, south-southeast, and east of Dartmouth) was also identified as a potential source area and may be related to evasion of GEM from the ocean surface. There were also some larger source areas scattered throughout Ohio, Pennsylvania, and New York, where there is a higher density of coal power plants. The major source areas for GOM in the winter were identified in southern and central Quebec, New Hampshire, Maine, New York, Pennsylvania, and Ohio. The known industrial $\mathrm{Hg}$ sources in these areas are from coal and oil power plants and industries, such as cement/concrete, iron/steel mills, metal casting, pulp and paper, and alumina $\left(\mathrm{Al}_{2} \mathrm{O}_{3}\right)$ and aluminum production. Similar to GEM source areas, the Atlantic Ocean (south-southeast of Dartmouth), northern Ontario, and western Quebec are potential major source areas of GOM in the winter, but there are no known industrial $\mathrm{Hg}$ sources in these regions. Unlike the GEM source areas, the coastal area between Maine and Nova Scotia was a major source area for GOM. For PBM, the largest potential source areas in the winter are located in various regions of Quebec with known metal mining and production and power plant sources. There were also source areas scattered throughout southwestern Ontario and Ohio, where $\mathrm{Hg}$ is emitted from chemical manufacturing, sewage treatment, and fossil fuel combustion sources. Central Ontario, northern parts of New York, Vermont, and New Hampshire, central Maine, and the Atlantic Ocean (south-southeast of Dartmouth) were also identified as strong source areas. However, these areas were not associated with known industrial $\mathrm{Hg}$ sources. Overall source areas for GOM and PBM were similar, except for the coastal area between Maine and Nova Scotia.

In the spring, potential major source areas for GEM were located northeast of Dartmouth towards Newfoundland and Labrador, and in western Quebec and central Ontario. Cement/concrete manufacturing, power plants, waste incineration, and metal ore mining, production and casting were the known industrial $\mathrm{Hg}$ sources in these areas. The Atlantic Ocean east and southeast of Dartmouth was also identified as a potential source area for GEM. For GOM, the largest source areas covered most of western to central Quebec, northern Ontario, New Brunswick, New Hampshire, and Maine. There were also some isolated source areas in Pennsylvania and Maryland. Some of these source areas contain industrial $\mathrm{Hg}$ sources, such as coal power plants and cement and gypsum production. Source areas for GOM were also identified along the eastern coast of Quebec and in the Atlantic Ocean (east and southwest of Dartmouth). But these 

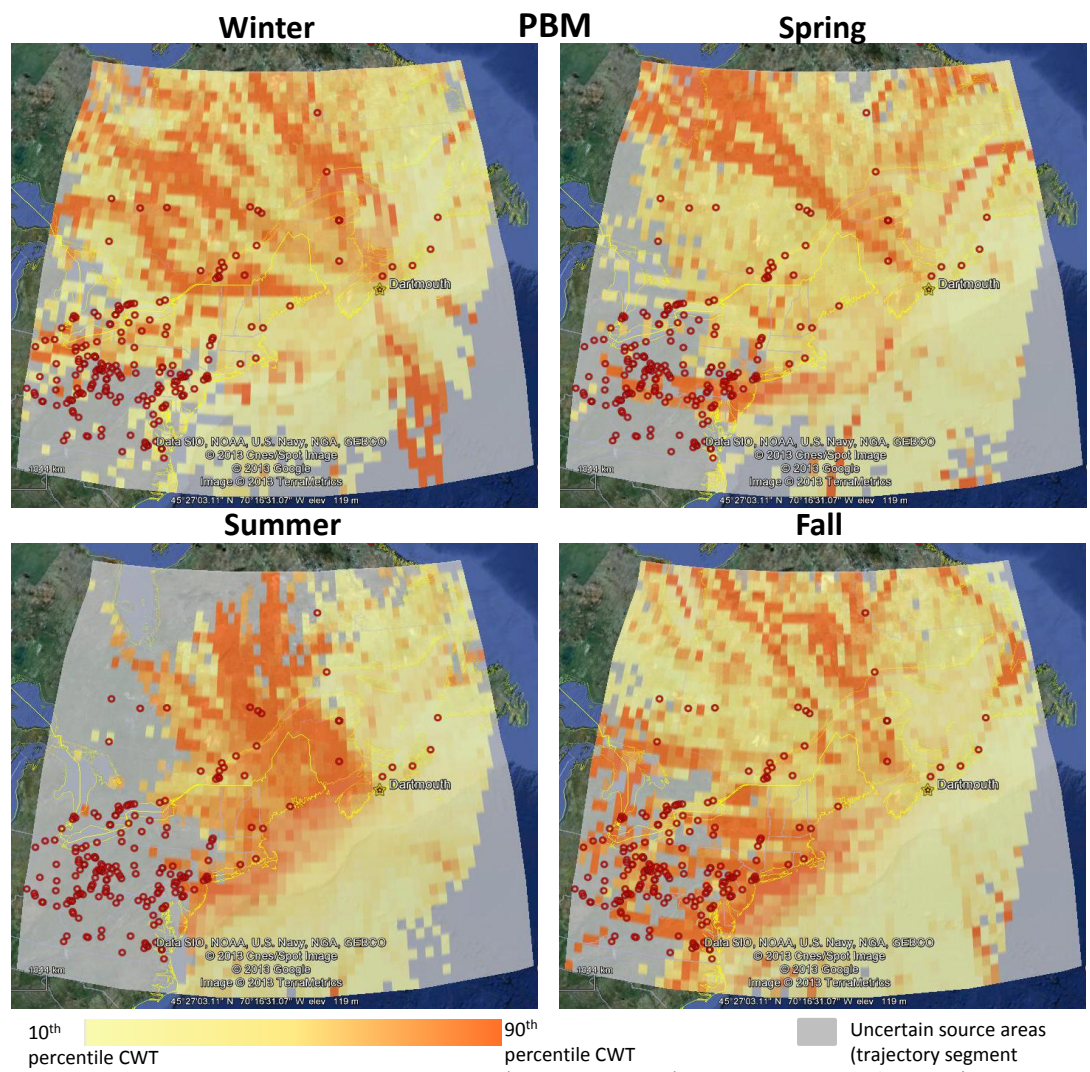

(non-source areas)

percentile CWT

(major source areas)

Uncertain source areas

(trajectory segmen

endpoints $<2$ )

Fig. 6. Same as Fig. 4 except for PBM.

are areas without known $\mathrm{Hg}$ point sources. The same source area along the coast of eastern Quebec was also a potential source area for PBM. Similar to GOM, major source areas were also found in Pennsylvania and Maryland, where there is a high concentration of coal power plants and industries. In addition to this, there was a source area for PBM that begins from just northwest of Dartmouth and diverges as it passed through northwestern Quebec and northern Ontario. However, it was not in the path of any known $\mathrm{Hg}$ point sources.

The summer CWT plots clearly had more uncertain source areas (grey-shaded) than those in winter and spring and illustrated that the back trajectories were shorter in the direction towards Quebec, Ontario, and northeastern US. But similar to other seasons, the trajectories in the summer traveled as far as eastern Canada and the Mid-Atlantic Ocean (Fig. 7). In the summer, the major source areas for GEM were found in southern and central Quebec, northeastern New York, and Massachusetts. A majority of these areas were not associated with known industrial Hg sources. The Atlantic Ocean south and southeast of Dartmouth was also a potential source area for GEM. Source areas for GOM were identified in southern, central, and eastern Quebec, and in central New York, southern Vermont and New Hampshire, and Massachusetts. These source areas coincided with known industrial $\mathrm{Hg}$ sources, such as metal ore mining, alumina and aluminum production, water and sewage treatment, cement production, and coal power plants. The Gulf of St. Lawrence near New Brunswick was also a potential GOM source area, but known industrial $\mathrm{Hg}$ sources do not exist. PBM source areas were concentrated in central and southeastern Quebec and New Brunswick, where $\mathrm{Hg}$ is emitted from alumina and aluminum production and a power plant. Source areas for PBM were also found along the US east coast and in New Jersey and eastern Pennsylvania.

The CWT plots for fall were different than those from other seasons because of the major source areas along the US east coast. Many of the large source areas are located in areas with a high density of known industrial $\mathrm{Hg}$ sources, such as southwestern Ontario, eastern Ohio, western and eastern regions of Pennsylvania, West Virginia, and Maryland. The sources include fossil fuel power plants and various industries that were mentioned previously.

A clear difference in the CWT plots between GEM and GOM or PBM was the major source areas in the Atlantic Ocean southeast of Dartmouth. This was a consistent source area for GEM all year round, whereas it was only a potential source area for GOM and PBM in the winter. Even though it suggests that evasion from the ocean was a source of GEM, 


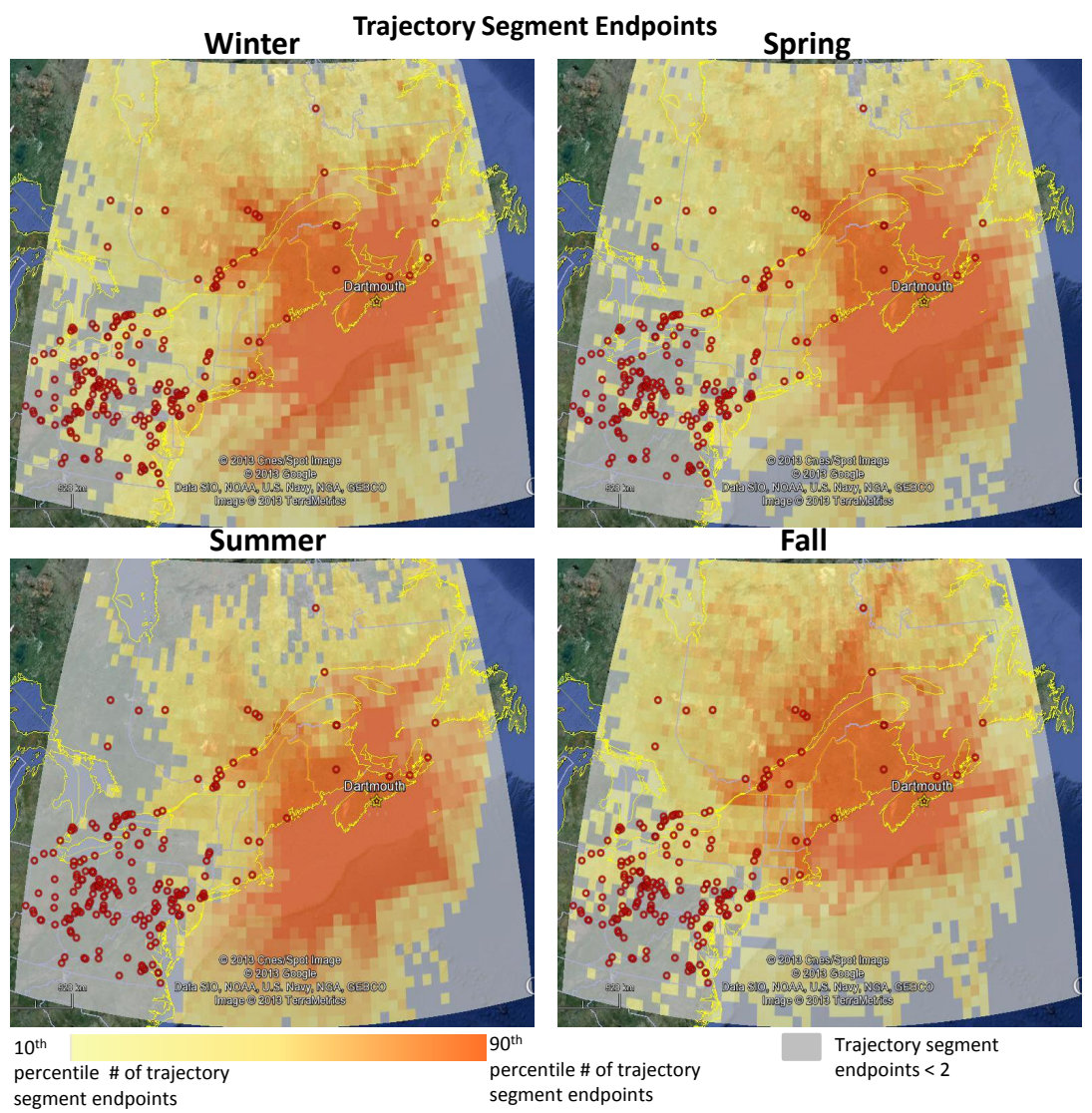

Fig. 7. Distances traveled by the $48 \mathrm{~h}$ back trajectories in each season from the Dartmouth site. Grid cells shown in orange have a large number of trajectory segment endpoints (note: there is always a larger number of trajectory segment endpoints close to the receptor site); those shown in yellow have few trajectory segment endpoints; those shown in grey have $<2$ trajectory segment endpoints. Red circles are the locations of known industrial $\mathrm{Hg}$ sources emitting $>5 \mathrm{~kg} \mathrm{of} \mathrm{Hg} \mathrm{yr}^{-1}$ in 2010 and 2011.

it is possible for back trajectories that are close to the coastline to have originated over land areas and then traveled over the ocean. If this was the case, large CWTs for PBM would also be observed over the ocean. It was previously shown that back trajectories originating from land and coastal areas was associated with PBM and other pollutants (e.g. $\mathrm{O}_{3}$, $\mathrm{PM}_{2.5}, \mathrm{SO}_{2}$ ) at a coastal site (Cheng et al., 2013). Differences between the GOM and PBM CWT plots were less discernible. The major source areas for both $\mathrm{Hg}$ species in winter, spring, and summer were predominately in Ontario and Quebec. In the fall, source areas for both $\mathrm{Hg}$ species were located in northeastern and east-central US. One difference that can be observed is the GOM source areas in the Atlantic Ocean between Maine and Nova Scotia and in the Gulf of St. Lawrence near New Brunswick, which were not found in most of the CWT plots for PBM (except in the summer). As a result of the shorter back trajectories in the summer, GEM, GOM, and PBM concentrations at Dartmouth were predominately affected by sources in Quebec and experienced minimal influence from regions with a high density of industrial $\mathrm{Hg}$ sources (southwestern Ontario and northeastern US).

\subsection{Effects of industrial Hg sources on CWTs}

Industrial $\mathrm{Hg}$ emissions from each grid cell were correlated with the CWTs from each grid cell. Since total Hg emissions from industrial sources were reported annually to the National Pollutant Release Inventory (Environment Canada, 2012) and Toxics Release Inventory (USEPA, 2012a), the total $\mathrm{Hg}$ emissions from 2010-2011 in each grid cell were compared with CWTs for GEM, GOM, and PBM over the same two-year period. Spearman rank correlation was applied to CWTs with $\geq 2$ trajectory segment endpoints per grid cell (excluding uncertain CWTs) and with industrial $\mathrm{Hg}$ emissions $>0$ (excluding grid cells with zero industrial $\mathrm{Hg}$ emissions). Overall, no correlations were observed between industrial $\mathrm{Hg}$ emissions and CWTs for GEM and GOM, but weak correlations were observed for PBM (Spearman $r=0.27$ ). This was comparable to the Spearman $r$ of 0.27 obtained by Choi et al. (2008) for the PSCF model values of PBM; however, strong Spearman correlations were obtained by Han et al. (2007) and Choi et al. (2008) for total gaseous mercury, GEM, and GOM. Correlations between industrial $\mathrm{Hg}$ emissions and modeled source areas may be dependent 
on the trajectory duration, use of total versus $\mathrm{Hg}$ speciesspecific emissions for comparison (Choi et al., 2008), and receptor location (Kabashnikov et al., 2011). The weak correlation results were likely not related to back trajectory segment endpoints. Unlike some trajectory statistical models that uses only the trajectory residence time in the grid cells as a criterion for identifying a potential source area, the CWT considers the concentrations as well. $\mathrm{The} \mathrm{Hg}$ concentrations need to be sufficiently high so that the calculated CWT is in the upper 10th percentile of the seasonal CWTs (the criterion to be considered a source location). As shown in Fig. 7, the locations of the back trajectory segment endpoints were completely different from the source areas in the CWT plots (Figs. 4 to 6$)$.

Even though CWTs did not increase with every unit increase in industrial $\mathrm{Hg}$ emissions, a further comparison found that CWTs corresponding to grid cells with $\geq 5 \mathrm{~kg}$ of industrial $\mathrm{Hg}$ emissions ( $\geq 25$ th percentile) were statistically larger than those with zero industrial $\mathrm{Hg}$ emissions $(p<0.05)$. The differences were only observed for GOM (CWT: 2.2 vs. $1.8 \mathrm{pg} \mathrm{m}^{-3}$ ) and PBM (CWT: 3.2 vs. $2.5 \mathrm{pg} \mathrm{m}^{-3}$ ), but not for GEM, which can be partially explained by their different lifetimes. Another potential reason why differences in the CWTs for GEM were not found between grid cells with industrial $\mathrm{Hg}$ emissions and those without is the large proportion of GEM emitted from nonindustrial sources, such as biomass combustion, forest fires, and surfaces of oceans, lakes, soil, and vegetation. Based on recent estimates of global $\mathrm{Hg}$ emissions, these non-industrial sources are emitting $5207 \mathrm{Mg}$ of mercury annually and include both primary emissions from natural sources and reemissions of previously-deposited $\mathrm{Hg}$ from natural and industrial sources (Pirrone et al., 2010). This estimate is about 2.2 times greater than the annual industrial $\mathrm{Hg}$ emissions reported by Pirrone et al. (2010). Therefore, even though there were grid cells with no $\mathrm{Hg}$ emitted to the air from industries, $\mathrm{Hg}$ emissions from other sources may have contributed to the CWT for GEM.

The major source areas that were identified from the CWT plots were often associated with areas that have no known industrial $\mathrm{Hg}$ sources. The analysis of CWTs and known $\mathrm{Hg}$ point source emissions revealed that overall $94 \%$ of elevated CWTs for GEM (defined as $\geq 90$ th percentile of CWTs from 2010-2011) were not associated with known industrial $\mathrm{Hg}$ emissions. The remaining $6 \%$ of the major source areas for GEM were related to known industrial $\mathrm{Hg}$ emissions. The percentages of major source areas that were related to known industrial $\mathrm{Hg}$ emissions were higher for GOM and PBM (9.6\% and $8.7 \%$, respectively). Out of all $\mathrm{Hg}$ species, PBM had the largest percentage of source areas associated with the largest range of $\mathrm{Hg}$ emissions ( $\geq 118 \mathrm{~kg}$ in 2010-2011), followed by GOM and then GEM. When the analysis was conducted separately for each season (Table 3), a higher percentage of elevated CWTs for GEM, GOM, and PBM were associated with industrial $\mathrm{Hg}$ emissions in the fall than other seasons. This was previously observed in the fall CWT plots, which illustrated that the major source areas were in regions with the highest density of industrial $\mathrm{Hg}$ sources (northeastern US). Over this region, CWTs for GEM, GOM, and PBM were found to be higher in the fall season (Fig. 8), suggesting that the regional industrial $\mathrm{Hg}$ point sources in the US northeast had larger impacts on the Dartmouth site in the fall. Speciated atmospheric $\mathrm{Hg}$ concentrations were lowest in the fall (Table 2), but the trajectories traveled over the region with industrial $\mathrm{Hg}$ sources more frequently in the fall than other seasons. The percentages were lowest in the winter and summer for GEM and PBM, and lowest in the summer for GOM.

To verify that the CWT method was accurate at determining potential source areas, grid cells with small CWTs ( $\leq 10$ th percentile or light-yellow areas in Figs. 4 to 6$)$ were analyzed with those associated with known industrial $\mathrm{Hg}$ emissions. It was expected that grid cells with small CWTs (i.e. non-source areas) should not have known industrial $\mathrm{Hg}$ emissions present. According to CWTs from 2010-2011, only $17.9 \%, 1.9 \%$, and $1.5 \%$ of the non-source areas for GEM, GOM, and PBM, respectively, were related to known industrial $\mathrm{Hg}$ emissions $\geq 5 \mathrm{~kg}$ over the 2010-2011 period. At even higher $\mathrm{Hg}$ emissions ( $\geq 42 \mathrm{~kg}$ over 2010-2011), the percent frequencies declined to $8.7 \%, 1.4 \%$, and $1 \%$, respectively. This may be a more effective method for assessing model accuracy than evaluating CWTs against industrial $\mathrm{Hg}$ emissions when $\mathrm{Hg}$ emissions from all sources have not been fully accounted for.

\subsection{The role of non-point sources, natural emissions, and other sources}

Since a majority of the large source areas determined from CWTs were not in regions with known industrial $\mathrm{Hg}$ sources, it is possible that these regions emit atmospheric $\mathrm{Hg}$ from non-point sources and natural sources. The global $\mathrm{Hg}$ emissions from natural sources (primary natural emissions and previously-deposited $\mathrm{Hg}$ ) reported in Pirrone et al. (2010) are applicable to the geographical domain for the Dartmouth site. Residential wood combustion is a typical source of mercury throughout rural communities in New York during winter (Choi et al., 2008; Huang et al., 2010). Annual Hg emissions from wood combustion in the US northeast can range from $0.15 \mathrm{~kg}$ in Delaware to $4.1 \mathrm{~kg}$ in Ohio according to the 2008 National Emissions Inventory (USEPA, 2012b). In comparison, residential oil combustion is even a larger source of $\mathrm{Hg}$ compared to wood combustion and natural gas in the US northeast ranging from $0.04 \mathrm{~kg}$ in Delaware to $265 \mathrm{~kg}$ in Ohio annually (USEPA, 2012b). Forest fires in Quebec have always been persistent sources of $\mathrm{Hg}, \mathrm{PM}_{2.5}$, and carbon, impacting sites in Massachusetts (Sigler et al., 2003), Baltimore (Sapkota et al., 2005), Philadelphia (Begum et al., 2005), and northern New York (Wang et al., 2010). From 2010-2011, there were 1019 forest fires across central to southern Quebec, which had burned a total area of $\sim 3300 \mathrm{~km}^{2}$ (NFD, 
Table 3. Percentage of major source areas ( $\geq 90$ th percentile seasonal CWTs for GEM, GOM, and PBM) associated with different ranges of industrial $\mathrm{Hg}$ emissions (25th, 50th, 75th percentile) in each grid cell.

\begin{tabular}{|c|c|c|c|c|c|c|c|c|c|c|c|c|}
\hline \multirow{2}{*}{$\begin{array}{l}\text { Industrial } \\
\mathrm{Hg} \text { emissions } \\
\text { range }(\mathrm{kg})\end{array}$} & \multicolumn{4}{|c|}{ GEM } & \multicolumn{4}{|c|}{ GOM } & \multicolumn{4}{|c|}{ PBM } \\
\hline & Winter & Spring & Summer & Fall & Winter & Spring & Summer & Fall & Winter & Spring & Summer & Fall \\
\hline 0 & $97.7 \%$ & $95.9 \%$ & $97.3 \%$ & $92.7 \%$ & $94.0 \%$ & $92.7 \%$ & $96.3 \%$ & $85.8 \%$ & $94.0 \%$ & $93.1 \%$ & $94.0 \%$ & $89.0 \%$ \\
\hline $5-15$ & $0.0 \%$ & $1.4 \%$ & $0.5 \%$ & $1.4 \%$ & $1.8 \%$ & $2.8 \%$ & $1.4 \%$ & $4.1 \%$ & $1.4 \%$ & $0.5 \%$ & $2.8 \%$ & $1.8 \%$ \\
\hline $15.1-42$ & $0.9 \%$ & $0.5 \%$ & $0.9 \%$ & $2.3 \%$ & $0.5 \%$ & $2.3 \%$ & $1.4 \%$ & $3.2 \%$ & $1.8 \%$ & $0.5 \%$ & $1.4 \%$ & $3.2 \%$ \\
\hline $42.1-118$ & $0.9 \%$ & $0.9 \%$ & $1.4 \%$ & $1.8 \%$ & $0.9 \%$ & $0.9 \%$ & $0.9 \%$ & $5.0 \%$ & $0.5 \%$ & $2.8 \%$ & $1.4 \%$ & $3.7 \%$ \\
\hline \multirow[t]{2}{*}{$\geq 118.1$} & $0.5 \%$ & $1.4 \%$ & $0.0 \%$ & $1.8 \%$ & $2.8 \%$ & $1.4 \%$ & $0.0 \%$ & $1.8 \%$ & $2.3 \%$ & $3.2 \%$ & $0.5 \%$ & $2.3 \%$ \\
\hline & $100.0 \%$ & $100.0 \%$ & $100.0 \%$ & $100.0 \%$ & $100.0 \%$ & $100.0 \%$ & $100.0 \%$ & $100.0 \%$ & $100.0 \%$ & $100.0 \%$ & $100.0 \%$ & $100.0 \%$ \\
\hline
\end{tabular}

2012; SOPFEU, 2012). Forest fires were also reported in 2010 in New Brunswick, Newfoundland and Labrador, and Ontario (NFD, 2012), and all of the northeastern states in the US in 2010 and 2011 (NIFC, 2012). Hg emissions from forest fires can be modeled using emission factors specific to the type of forests; however, the uncertainties can reach up to $50 \%$ of the estimate (Wiedinmyer and Friedli, 2007). The CWT plots have shown that the potential major source areas are located in regions where different types of residential combustion and forest fires are also occurring. As shown in Fig. 8, CWTs for GEM over the central and southern Quebec regions were larger in the summer than other seasons, which is consistent with the timing of the forest fire season.

$\mathrm{Hg}$ emissions from the surface of the ocean, forests, and land are potential sources affecting Dartmouth. These emissions make up at least $60 \%$ of the global emissions from natural sources (Pirrone et al., 2010). GEM fluxes from the Atlantic Ocean (Laurier et al., 2003; Sunderland and Mason, 2007), forest floor (Choi and Holsen, 2009), and land surfaces (Eckley and Branfireun, 2008) have been reported. In this study, forested areas in northern Ontario, Quebec, New Brunswick, and the US northeast were found to have elevated CWTs. The CWT plots in Figs. 4 and 5 identified the Atlantic Ocean as a potential major source area affecting Dartmouth. GEM is released from oceans due to evasion and GOM can be produced over the ocean by in situ GEM oxidation involving oxidants, such as reactive $\mathrm{Br}$ that is emitted from the oceans with sea salt aerosols. The GOM source areas that were located in the Atlantic Ocean between Maine and Nova Scotia and in the Gulf of St. Lawrence near New Brunswick could be the result of the oxidation of GEM by $\mathrm{Br}$. These areas often experience large tidal waves that generate the strong turbulence needed to form sea-salt aerosols and $\mathrm{Br}$ (Keene et al., 2007). The ocean is likely not a source of PBM $(\leq 2.5 \mu \mathrm{m})$ because there are no emission sources from the ocean. Therefore, there were more source areas over the ocean for GEM and GOM than PBM. The CWT source areas over the Atlantic Ocean were comparable to the net GEM evasion distribution obtained from the GEOS-Chem model simulations by Soerensen et al. (2010). The evasion "hotspot" was located over the Mid-Atlantic Ocean in So- erensen et al. (2010), which is consistent with the larger CWTs for GEM in these areas during winter, summer, and fall (Fig. 4). The higher evasion rate of GEM in the winter/spring compared to summer/fall (Soerensen et al., 2010) was also found in this study. Figure 8 illustrates the CWTs for GEM were larger over the Atlantic Ocean in the winter than other seasons.

Finally, there are potential sources within the geographical domain for Dartmouth that lack Hg emissions data. These include marine vessels in shipping ports concentrated in the US east coast and Gulf of St. Lawrence, offshore petroleum rigs in the Atlantic Ocean, and open-pit mining of coal in the Appalachian Mountains (West Virginia). These regions were identified as areas with elevated CWTs. Speciated atmospheric $\mathrm{Hg}$ in the Adriatic Sea were attributed to nearby shipping and port activities (Sprovieri et al., 2010), and particulate matter emissions from marine diesel combustion contain trace amounts of metals, including Hg (USEPA, 2011). While elevated CWTs over the Atlantic Ocean might be indicative of evasion of GEM, it is possible that isolated areas with elevated CWTs (southeast of Dartmouth) are related to $\mathrm{Hg}$ emissions from offshore platforms. $\mathrm{Hg}$ emissions from offshore petroleum rigs could come from power generation to sustain operations on the platform. There are currently two active offshore natural gas projects $\sim 225 \mathrm{~km}$ southeast of Dartmouth near Sable Island (CNSOPB, 2012). Open-pit coal mining could be a source of PBM because the particulate matter emitted contains trace amounts of $\mathrm{Hg}$. The openpit coal mine in the Appalachian Mountains of West Virginia was a region that was associated with elevated CWTs for PBM in the fall. It is important to emphasize that there is little information on atmospheric $\mathrm{Hg}$ emissions from these sources; therefore, field measurements are needed to quantify the $\mathrm{Hg}$ emissions.

\subsection{Model uncertainties and limitations}

One of the major sources of uncertainty of the CWT model is back trajectory modeling. Wind field errors, modeling of vertical motion, turbulence in the PBL, and starting positions are the factors contributing to trajectory uncertainties (Scheele, 

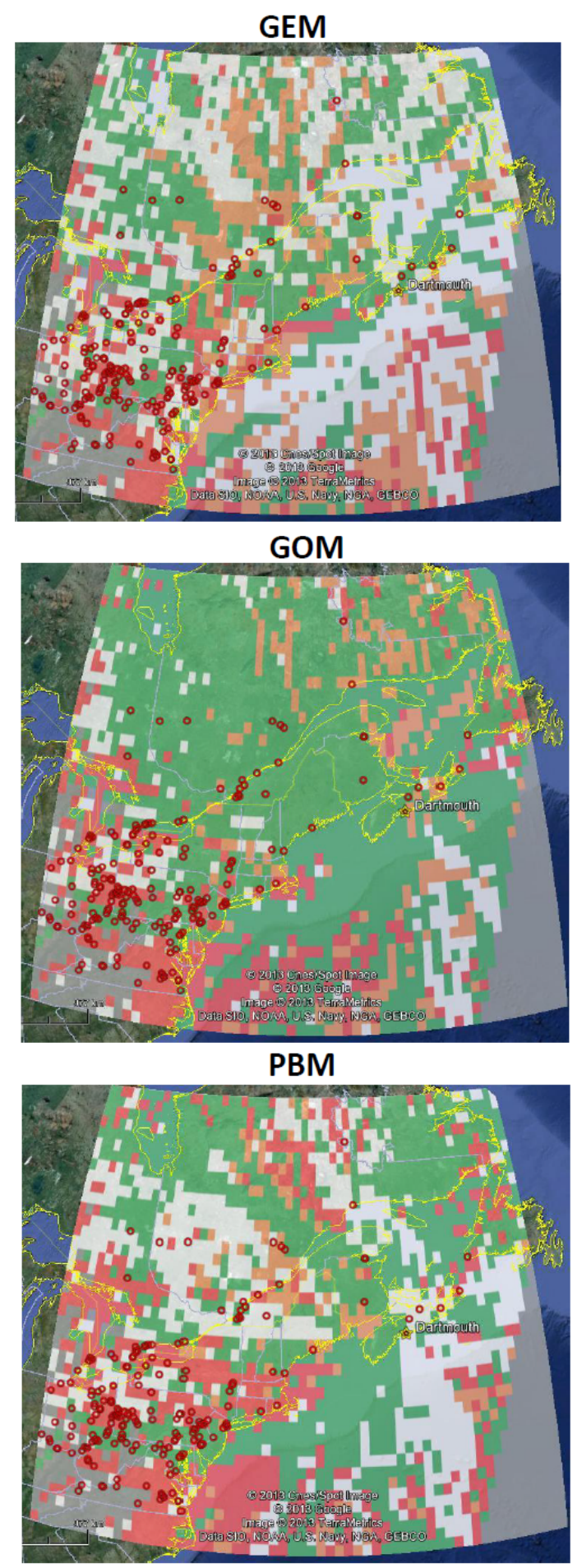

Fig. 8. Geographical distribution of the largest seasonal CWTs for GEM, GOM and PBM. Winter: grid cells with white color; Spring: green; Summer: orange; and Fall: red. Grid cells shown in grey were not used in the calculation of CWT for any season because there were $<2$ trajectory segment endpoints. Red circles are the locations of known industrial $\mathrm{Hg}$ sources emitting $>5 \mathrm{~kg}$ of $\mathrm{Hg} \mathrm{yr}^{-1}$ in 2010 and 2011.
1996; Stohl, 1998). Wind field errors affect the trajectory position and increase with trajectory duration (Scheele, 1996; Stohl, 1998). The reasons for using a $48 \mathrm{~h}$ trajectory duration as oppose to a longer duration was because it reduces the uncertainties in the trajectory position and potential for dry and wet deposition of shorter-lived $\mathrm{Hg}$ species, e.g. GOM and PBM. The $48 \mathrm{~h}$ trajectories were also capable of reaching the US northeast and southern Ontario, where most of the regional $\mathrm{Hg}$ emission sources are located. There are also benefits with using a longer trajectory duration for GEM because it can simulate the long range transport of GEM and sources from a global scale. But in order for this to be computationally feasible, coarser grid sizes may be required and a potential trade off could be the reduced precision in the modeling of source areas. The CWT model could not differentiate between source areas that are associated with surface emissions and those associated with point sources. Even though it is possible to examine the trajectory segment endpoints in the grid cells at different altitudes, vertical mixing and turbulence in the boundary layer causes uncertainties about the origin of the $\mathrm{Hg}$ emissions in each grid cell. Uncertainties in the trajectory positions can be clearly illustrated using ensemble trajectories in which small offsets in the meteorological data are applied. The starting height in the HYSPLIT model ideally needs to be $>250 \mathrm{~m}$ for running trajectory ensembles because of these offsets. A starting height of $100 \mathrm{~m}$ a.s.l. was selected because it is more representative of the height of the $\mathrm{Hg}$ measurements, which was close to sea level. In the CWT model equation, the pollutant concentrations correspond to the arrival of the back trajectory at the site. Future speciated atmospheric $\mathrm{Hg}$ measurements at this site need to be taken at a higher elevation in order to apply a higher starting height and ensemble trajectories.

Uncertainties in $\mathrm{Hg}$ emissions data from non-point sources (e.g. emissions from ocean, terrestrial surface, forest fires, residential wood combustion, shipping, etc.) is a major issue in this study because these data along with industrial $\mathrm{Hg}$ emissions data from point sources are needed to assess the accuracy of the CWT model at identifying $\mathrm{Hg}$ sources affecting Dartmouth. A detailed comparison between the CWT model source areas and industrial $\mathrm{Hg}$ emissions from the grid cells were conducted because point source emissions data are updated annually and the precise locations provided are compatible with the sampling period of the speciated atmospheric $\mathrm{Hg}$ measurements and the high resolution grid of the CWT model. Although global mercury emissions inventory (Pirrone et al., 2010) and 2008 NEI (USEPA, 2012b) have data on $\mathrm{Hg}$ emissions from oceans, forests, and different types of residential combustion, the CWT method does require having more precise locations of these sources due to the nature of the grid cells, which is not available from these inventories. Since sources like soil, wildfires, and oceans can occupy a large area (and numerous grid cells), there are also some uncertainties on whether the $\mathrm{Hg}$ emissions occur uniformly over the entire area. Even with the absence of this data for 
non-point sources, the modeled source areas were compared with non-point sources reported in other emissions inventory, literature, and model simulations.

\section{Conclusions}

Concentration-Weighted Trajectory (CWT), a trajectory statistical model that combines pollutant concentrations and back trajectory data, was used to identify potential source areas impacting speciated atmospheric $\mathrm{Hg}$ at an urban site in Dartmouth, Nova Scotia. Some of the source areas were associated with known industrial sources and fossil fuel power plants, which were typically located in southern Quebec and Ontario, and in Ohio, Pennsylvania, New York, West Virginia, and Maryland. There were also modeled source areas that are in regions with no known industrial $\mathrm{Hg}$ sources, such as the Atlantic Ocean and northern parts of Ontario, Quebec, Vermont, New Hampshire, and Maine. Source areas also varied by season with noticeably more source areas in regions with high density of industrial $\mathrm{Hg}$ emissions in the fall than other seasons. Analysis of wind speeds and wind direction found that local marine transportation, shipping ports, and traffic on the Halifax harbor bridges were in the wind directions coinciding with elevated GEM, GOM, and PBM concentrations.

While only weak correlations were found between CWTs for PBM and $\mathrm{Hg}$ emissions from industrial sources, CWTs for GOM and PBM in grid cells with $\geq 5 \mathrm{~kg} \mathrm{Hg}$ emitted were statistically larger than those with no industrial $\mathrm{Hg}$ emissions. There was however no difference observed for GEM. Comparison of CWTs with industrial $\mathrm{Hg}$ emissions was not an ideal method to assess the CWT model's accuracy in identifying source areas because not all sources of $\mathrm{Hg}$ have been included. In this study, the accuracy of the CWT model was assessed by comparing the non-source areas (CWTs $\leq 10$ th percentile) with industrial $\mathrm{Hg}$ emissions in each grid cell. As expected, only a small percentage of the non-source areas were associated with known $\mathrm{Hg}$ emissions and this percentage further decreased with higher levels of $\mathrm{Hg}$ emissions. Large CWTs were potentially in regions where there are $\mathrm{Hg}$ emissions from residential wood and oil combustion, forest fires, shipping ports, and oceans as indicated in National Emissions Inventory (USEPA, 2012b) and research-derived $\mathrm{Hg}$ emission inventories (Pirrone et al., 2010), but precise locations of these sources are necessary to conduct statistical comparisons with model results. There are also sources that are potentially relevant to Dartmouth (e.g. open-pit coal mining in West Virginia to local gypsum mining and offshore rigs), which require further field measurements to verify whether or not they are $\mathrm{Hg}$ sources.

CWT identifies potential source areas affecting a particular site based on ambient air concentrations and back trajectory data, but the interpretation of the sources is still necessary without a comprehensive $\mathrm{Hg}$ emissions database. Since this is a source of uncertainty, future applications of Trajectory Statistical Methods or Hybrid Receptor Models on speciated atmospheric Hg should develop a better method of incorporating $\mathrm{Hg}$ emissions from all types of sources to allow for a proper statistical comparison with model results. This post analysis hopefully will address issues with model accuracy, uncertainties, and limitations.

Acknowledgements. The authors acknowledge Robert Keenan at Environment Canada for compiling the wind data from Dartmouth and NOAA Air Resources Laboratory (ARL) for the provision of the HYSPLIT transport and dispersion model and READY website (http://ready.arl.noaa.gov) used in this publication.

Edited by: R. Ebinghaus

\section{References}

Abbott, M. L., Lin, C.-J., Martian, P., and Einerson, J. J.: Atmospheric mercury near Salmon Falls Creek Reservoir in southern Idaho, Appl. Geochem., 23, 438-453, 2008.

Beauchamp, S., Tordon, R., Phinney, L., Abraham, K., Pinette, A., MacIntosh, A., Rencz, A., Wong, H., and Dalziel, J.: Air-surface exchange of mercury in natural and anthropogenically impacted landscapes in Atlantic Canada, Geochem.-Explor. Env. A., 2, 157-165, doi:10.1144/1467-787302-019, 2002.

Begum, B. A., Kim, E., Jeong, C.-H., Lee, D.-W., and Hopke, P. K.: Evaluation of the potential source contribution function using the 2002 Quebec forest fire episode, Atmos. Environ., 39, 37193724, doi:10.1016/j.atmosenv.2005.03.008, 2005.

Brooks, S., Luke, W., Cohen, M., Kelly, P., Lefer, B., and Rappenglu, B.: Mercury species measured atop the Moody Tower TRAMP site, Houston, Texas, Atmos. Environ., 44, 4045-4055, 2010.

Canada-Nova Scotia Offshore Petroleum Board (CNSOPB): Offshore projects, available at: http://www.cnsopb.ns.ca/ offshore-activity/offshore-projects, last access: 30 December 2012.

Cheng, I., Lu, J., and Song, X.: Studies of Potential Sources that Contributed to Atmospheric Mercury in Toronto, Canada, Atmos. Environ., 43, 6145-6158, 2009.

Cheng, I., Zhang, L., Blanchard, P., Graydon, J. A., and Louis, V. L. St.: Source-receptor relationships for speciated atmospheric mercury at the remote Experimental Lakes Area, northwestern Ontario, Canada, Atmos. Chem. Phys., 12, 1903-1922, doi:10.5194/acp-12-1903-2012, 2012.

Cheng, I., Zhang, L., Blanchard, P., Dalziel, J., Tordon, R., Huang, J., and Holsen, T. M.: Comparisons of Mercury Sources and Atmospheric Mercury Processes between a Coastal and Inland site, J. Geophys. Res.-Atmos., 118, 2434-2443, doi:10.1002/jgrd.50169, 2013.

Choi, H.-D. and Holsen, T. M.: Gaseous mercury fluxes from the forest floor of the Adirondacks, Environ. Pollut., 157, 592-600; doi:10.1016/j.envpol.2008.08.020, 2009.

Choi, H.-D., Holsen, T. M., and Hopke, P. K.: Atmospheric Mercury $(\mathrm{Hg})$ in the Adirondacks: Concentrations and Sources, Environ. Sci. Technol., 42, 5644-5653, 2008. 
Draxler, R. R. and Rolph, G. D.: HYSPLIT Model, Access via NOAA ARL READY Website. NOAA Air Resources Laboratory, Silver Spring, MD, available at: http://www.arl.noaa.gov/ ready/hysplit4.html, last access: 30 December 2012.

Ebinghaus, R., Dommergue, A., Jaffe, D., Keeler, G. J., Kock, H. H., Pirrone, N., Schmeltz, D., and Sprovieri, F.: Chapter 2: Observations, in: United Nations Economic Commission for Europe, Hemispheric Transport of Air Pollution 2010, Part B: Mercury, Air Pollution Studies No. 18, edited by: Pirrone, N. and Keating, T., ISSN 1014-4625, United Nations Publication, Geneva, 2, 27-32, 2010.

Eckley, C. S. and Branfireun, B.: Gaseous mercury emissions from urban surfaces: controls and spatiotemporal trends, Appl. Geochem., 23, 369-383, 2008.

Environment Canada: National Pollutant Release Inventory (NPRI), available at: http://www.ec.gc.ca/inrp-npri/default.asp? lang=En\&n=4A577BB9-1, last access: 30 December 2012.

Fu, X., Feng, X., Qiu, G., Shang, L., and Zhang, H.: Speciated atmospheric mercury and its potential source in Guiyang, China, Atmos. Environ., 45, 4205-4212, doi:10.1016/j.atmosenv.2011.05.012, 2011.

Gabriel, M. C., Williamson, D. G., Brooks, S., and Lindberg, S.: Atmospheric speciation of mercury in two contrasting southeastern US airsheds, Atmos. Environ., 39, 4947-4958, 2005.

Gustin, M. S. and Jaffe, D.: Reducing the uncertainty in measurement and understanding of mercury in the atmosphere, Environ. Sci. Technol., 44, 2222-2227, 2010.

Gustin, M. and Ladwig, K.: Laboratory Investigation of Hg Release from Flue Gas Desulfurization Products, Environ. Sci. Technol., 44, 4012-4018, doi:10.1021/es903673q, 2010.

Gustin, S. M., Weiss-Penzias, P. S., and Peterson, C.: Investigating sources of gaseous oxidized mercury in dry deposition at three sites across Florida, USA, Atmos. Chem. Phys., 12, 9201-9219, doi:10.5194/acp-12-9201-2012, 2012.

Halifax Harbour Bridges (HHB), available at: https://www.hdbc. ca/, last access: 30 December 2012.

Han, Y.-J., Holsen, T. M., Hopke, P. K., and Yi, S.-M.: Comparison between Back-Trajectory Based Modeling and Lagrangian Backward Dispersion Modeling for Locating Sources of Reactive Gaseous Mercury, Environ. Sci. Technol., 39, 1715-1723, 2005.

Han, Y.-J., Holsen, T. M., and Hopke, P. K.: Estimation of source locations of total gaseous mercury measured in New York State using trajectory-based models, Atmos. Environ., 41, 6033-6047, 2007.

Hopke, P. K. and Cohen, D. D.: Application of receptor modeling methods, Atmos. Pollut. Res., 2, 122-125, 2011.

Huang, J., Choi, H.-D., Hopke, P. K., and Holsen, T. M.: Ambient Mercury Sources in Rochester, NY: Results from Principle Components Analysis (PCA) of Mercury Monitoring Network Data, Environ. Sci. Technol., 44, 8441-8445, 2010.

Jeong, U., Kim, J., Lee, H., Jung, J., Kim, Y. J., Song, C. H., and Koo, J.-H.: Estimation of the contributions of long range transported aerosol in East Asia to carbonaceous aerosol and PM concentrations in Seoul, Korea using highly time resolved measurements: a PSCF model approach, J. Environ. Monit., 13, 19051918, doi:10.1039/c0em00659a, 2011.
Kabashnikov, V. P., Chaikovsky, A. P., Kucsera, T. L., and Metelskaya, N. S.: Estimated accuracy of three common trajectory statistical methods, Atmos. Environ., 45, 5425-5430, 2011.

Keene, W. C., Stutz, J., Pszenny, A. A. P., Maben, J. R., Fischer, E. V., Smith, A. M., von Glasow, R., Pechtl, S., Sive, B. C., and Varner, R. K.: Inorganic chlorine and bromine in coastal New England air during summer, J. Geophys. Res., 112, D10S12, doi:10.1029/2006JD007689, 2007.

Landis, M. S., Lewis, C. W., Stevens, R. K., Keeler, G. J., Dvonch, J. T., and Tremblay, R. T.: Ft. McHenry tunnel study: Source profiles and mercury emissions from diesel and gasoline powered vehicles, Atmos. Environ., 41, 8711-8724, 2007.

Laurier, F. J. G., Mason, R. P., Whalin, L., and Kato, S.: Reactive gaseous mercury formation in the North Pacific Ocean's marine boundary layer: A potential role of halogen chemistry, J. Geophys. Res., 108, 4529, doi:10.1029/2003JD003625, 2003.

Liu, B., Keeler, G. J., Dvonch, J. T., Barres, J. A., Lynam, M. M., Marsik, F. J., and Morgan, J. T.: Temporal variability of mercury speciation in urban air, Atmos. Environ., 41, 1911-1923, 2007.

Liu, B., Keeler, G. J., Dvonch, J. T., Barres, J. A., Lynam, M. M., Marsik, F. J., and Morgan, J. T.: Urban-rural differences in atmospheric mercury speciation, Atmos. Environ., 44, 2013-2023, 2010.

Lyman, S. N. and Gustin, M. S.: Determinants of atmospheric mercury concentrations in Reno, Nevada, U.S.A., Sci. Total Environ., 408, 431-438, 2009.

Lynam, M. M. and Keeler, G. J.: Source-receptor relationships for atmospheric mercury in urban Detroit, Michigan, Atmos. Environ., 40, 3144-3155, 2006.

Maprani, A. C., Al, T. A., Macquarrie, K. T., Dalziel, J. A., Shaw, S. A., and Yeats, P. A.: Determination of mercury evasion in a contaminated headwater stream, Environ. Sci. Technol., 39, 16791687, 2005.

Nair, U. S., Wu, Y., Walters, J., Jansen, J., and Edgerton, E. S.: Diurnal and seasonal variation of mercury species at coastalsuburban, urban, and rural sites in the southeastern United States, Atmos. Environ., 47, 499-508, 2012.

National Atmospheric Deposition Program (NADP): AMNet Documents, available at: http://nadp.sws.uiuc.edu/amn/docs.aspx, last access: 30 December 2012.

National Forestry Database (NFD): Forest Fires - National Tables, available at: http://nfdp.ccfm.org/fires/national_e.php, last access: 30 December 2012.

National Interagency Fire Centre (NIFC): Statistics, available at: http://www.nifc.gov/fireInfo/fireInfo_statistics.html, last access: 30 December 2012.

Parsons, M., Campbell, J. L., and Jamieson, H.: Arsenic, thallium and mercury speciation in dust from abandoned gold mine tailings in Nova Scotia, Metals in the Human Environment Strategic Network (MITHE-SN), University of Guelph Library, available at: http://atrium.lib.uoguelph.ca:8080/xmlui/handle/10214/2155 (last access: 30 December 2012), 2010.

Parsons, M. B., LeBlanc, K. W. G., Hall, G. E. M., Sangster, A. L., Vaive, J. E., and Pelchat, P.: Environmental geochemistry of tailings, sediments and surface waters collected from 14 historical gold mining districts in Nova Scotia, Geological Survey of Canada, Open File 7150, doi:10.4095/291923, available at: http://geoscan.ess.nrcan.gc.ca/, last access: 30 December 2012. 
Peterson, C., Gustin, M., and Lyman, S.: Atmospheric mercury concentrations and speciation measured from 2004 to 2007 in Reno, Nevada, USA, Atmos. Environ., 43, 4646-4654, 2009.

Pirrone, N., Cinnirella, S., Feng, X., Finkelman, R. B., Friedli, H. R., Leaner, J., Mason, R., Mukherjee, A. B., Stracher, G. B., Streets, D. G., and Telmer, K.: Global mercury emissions to the atmosphere from anthropogenic and natural sources, Atmos. Chem. Phys., 10, 5951-5964, doi:10.5194/acp-10-59512010, 2010.

Port of Halifax, available at: http://www.portofhalifax.ca/english/ about-us/index.html, last access: 30 December 2012.

Province of Nova Scotia: Historical gold mine tailings, available at: http://www.gov.ns.ca/nse/contaminatedsites/goldmines. asp, last access: 30 December 2012.

Rolph, G. D.: Real-time Environmental Applications and Display System (READY), Website, NOAA Air Resources Laboratory, Silver Spring, MD, available at: http://www.arl.noaa.gov/ready/ hysplit4.html, last access: 30 December 2012.

Rutter, A. P., Schauer, J. J., Lough, G. C., Snyder, D. C., Kolb, C. J., Klooster, S. V., Rudolf, T., Manolopoulos, H., and Olson, M. L.: A comparison of speciated atmospheric mercury at an urban center and an upwind rural location, J. Environ. Monit., 10, 102108, 2007.

Rutter, A. P., Snyder, D. C., Stone, E. A., Schauer, J. J., GonzalezAbraham, R., Molina, L. T., Márquez, C., Cárdenas, B., and de Foy, B.: In situ measurements of speciated atmospheric mercury and the identification of source regions in the Mexico City Metropolitan Area, Atmos. Chem. Phys., 9, 207-220, doi:10.5194/acp-9-207-2009, 2009.

Sapkota, A., Symons, J. M., Kleissl, J., Wang, L., Parlange, M. B., Ondov, J., Breysse, P. N., Diette, G. B., Eggleston, P. A., and Buckley, T. J.: Impact of the 2002 Canadian forest fires on particulate matter air quality in Baltimore city, Environ. Sci. Technol., 39, 24-32, 2005.

Scheele, M. P., Siegmund, P. C., and Velthoven, P. F. J.: Sensitivity of trajectories to data resolution and its dependence on the starting point: in or outside a tropopause fold, Meteorol. Appl., 3, 267-273, 1996.

Selin, N. E. and Jacob, D. J.: Seasonal and spatial patterns of mercury wet deposition in the United States: Constraints on the contribution from North American anthropogenic sources, Atmos. Environ., 42, 5193-5204, 2008.

Shock, S. S., Noggle, J. J., Bloom, N., and Yost, L. J.: Evaluation of Potential for Mercury Volatilization from Natural and FGD Gypsum Products Using Flux-Chamber Tests, Environ. Sci. Technol., 43, 2282-2287, doi:10.1021/es802872n, 2009.

Sigler, J. M., Lee, X., and Munger, W.: Emission and long-range transport of gaseous mercury from a large-scale Canadian boreal forest fire, Environ. Sci. Technol., 37, 4343-4347, 2003.

Société de protection des forêts contre le feu (SOPFEU): Maps, available at: http://www.sopfeu.qc.ca/en/ report-on-fire-situation/maps, last access: 30 December 2012.

Soerensen, A. L., Sunderland, E. M., Holmes, C. D., Jacob, D. J., Yantosca, R. M., Skov, H., Christensen, J. H., Strode, S. A., and Mason, R. P.: An improved global model for air-sea exchange of mercury: high concentrations over the North Atlantic. Environ. Sci. Technol., 44, 8574-8580, doi:10.1021/es102032g, 2010.
Song, X., Cheng, I., and Lu, J.: Annual atmospheric mercury species in downtown Toronto, Canada, J. Environ. Monit., 11, 660-669, 2009.

Sprovieri, F., Hedgecock, I. M., and Pirrone, N.: An investigation of the origins of reactive gaseous mercury in the Mediterranean marine boundary layer, Atmos. Chem. Phys., 10, 3985-3997, doi:10.5194/acp-10-3985-2010, 2010.

Statistics Canada: Focus on Geography Series, 2011 Census, Statistics Canada Catalogue no. 98-310-XWE2011004, Ottawa, Ontario, Analytical products, 2011 Census, available at: http://www12.statcan.gc.ca/census-recensement/2011/ as-sa/fogs-spg/Facts-csd-eng.cfm?Lang=Eng\&TAB=1\&GK= CSD\&GC=1209034, last access: 30 December 2012.

Steffen, A., Scherz, T., Olson, M., Gay, D., and Blanchard, P.: A Comparison of data quality control protocols for atmospheric mercury speciation measurements, J. Environ. Monit., 14, 752765, doi:10.1039/c2em10735j, 2012.

Stohl, A.: Computation, accuracy and applications of trajectories a review and bibliography, Atmos. Environ., 32, 947-966, 1998.

Sunderland, E. M. and Mason, R. P.: Human impacts on open ocean mercury concentrations, Global Biogeochem. Cy., 21, GB4022, doi:10.1029/2006GB002876, 2007.

Telmer, K. H. and Veiga, M. M.: World emissions of mercury from artisanal and small scale gold mining, in: Mercury Fate and Transport in the Global Atmosphere, edited by: Mason, R. and Pirrone, N., Springer Science \& Media Business, New York, USA, 131-172, doi:10.1007/978-0-387-93958-2_6, 2009.

USEPA: Regulatory Impact Analysis: Control of Emissions of Air Pollution from Category 3 Marine Diesel Engines, available at: http://www.epa.gov/otaq/regs/nonroad/marine/ci/420r09019. pdf (last access: 11 February 2013), 2011.

USEPA: Toxics Release Inventory (TRI) Explorer, available at: http: //www.epa.gov/triexplorer/facility.htm, last access: 30 December 2012a.

USEPA: 2008 National Emissions Inventory (NEI) Data, available at: http://www.epa.gov/ttn/chief/net/2008inventory.html, last access: 30 December 2012 b.

Wang, Y. Q., Zhang, X. Y., and Draxler, R. R.: TrajStat: GIS-based software that uses various trajectory statistical analysis methods to identify potential sources from long-term air pollution measurement data, available at: http://www.meteothinker.com/ Documents/Wang_TrajStat_Manuscript.pdf (last access: 30 December 2012), 2009.

Wang, Y., Huang, J., Zananski, T. J., Hopke, P. K., and Holsen, T. M.: Impacts of the Canadian Forest Fires on Atmospheric Mercury and Carbonaceous Particles in Northern New York, Environ. Sci. Technol., 44, 8435-8440, 2010.

Watson, J. G., Chen, L. W. A., Chow, J. C., Doraiswamy, P., and Lowenthal, D. H.: Source Apportionment: Findings from the U.S. Supersites Program, J. Air Waste Manage., 58, 265-288, doi:10.3155/1047-3289.58.2.265, 2008.

Weiss-Penzias, P. S., Gustin, M. S., and Lyman, S. N.: Sources of gaseous oxidized mercury and mercury dry deposition at two southeastern U.S. sites, Atmos. Environ., 45, 4569-4579, doi:10.1016/j.atmosenv.2011.05.069, 2011.

Wiedinmyer, C. and Friedli, H.: Mercury emission estimates from fires: an initial inventory for the United States, Environ. Sci. Technol., 41, 8092-8098, 2007. 
Wong, H. K. T., Gauthier, A., Beauchamp, S., and Tordon, R.: Impact of toxic metals and metalloids from the Caribou goldmining areas in Nova Scotia, Canada, Geochem.-Explor. Env. A., 2, 235-241, doi:10.1144/1467-787302-027, 2002.

$\mathrm{Xu}, \mathrm{X}$. and Akhtar, U. S.: Identification of potential regional sources of atmospheric total gaseous mercury in Windsor, Ontario, Canada using hybrid receptor modeling, Atmos. Chem. Phys., 10, 7073-7083, doi:10.5194/acp-10-7073-2010, 2010.
Zhang, L., Blanchard, P., Gay, D. A., Prestbo, E. M., Risch, M. R., Johnson, D., Narayan, J., Zsolway, R., Holsen, T. M., Miller, E. K., Castro, M. S., Graydon, J. A., Louis, V. L. St., and Dalziel, J.: Estimation of speciated and total mercury dry deposition at monitoring locations in eastern and central North America, Atmos. Chem. Phys., 12, 4327-4340, doi:10.5194/acp-12-43272012, 2012. 